\author{
Paul Mason \\ Baylor University \\ (254) 710-6129 \\ p_mason@baylor.edu \\ Steven Utke \\ University of Connecticut \\ (860) 486-2374 \\ sutke@uconn.edu \\ and \\ Brian Williams* \\ Indiana University \\ (812) 855-5725 \\ bw63@indiana.edu
}

November 2, 2020

Keywords: Tax Evasion, Tax Morale, Quality of Government, Perceived Influence, Procedural Fairness

JEL codes: H26

Data Availability: Data used in this study are available from public sources identified in the paper, except as otherwise specified.

*Corresponding Author: Brian Williams, Kelley School of Business, Indiana University, Bloomington IN 47403, 812-855-5725, bw63@indiana.edu

We gratefully acknowledge the support of our respective institutions. This paper has benefited from helpful comments from Shannon Chen (discussant), Jennifer Glenn, David Guenther, Brad Hepfer, Jenny Luchs, Sean McGuire, Bridget Stomberg, John Robinson, Connie Weaver (editor), Dave Weber, two anonymous reviewers, the University of Arizona Tax Readings Group, the Texas A\&M Tax Readings Group, conference participants at the 2018 American Taxation Association Midyear meeting, and workshop participants at the University of Connecticut. The analysis in this paper uses data from the World Bank Group's Enterprise Surveys and was accessed by the authors under a strict confidentiality agreement. The analysis, interpretations, and conclusions expressed in this paper are those of the authors and do not represent official positions of the World Bank. 


\title{
Why Pay Our Fair Share? How Perceived Influence over Laws Affects Tax Evasion
}

\begin{abstract}
We examine how the relation between taxpayers and their government affects tax evasion. Specifically, we examine how perceived influence over government policymaking affects firms' decisions to evade tax. We argue that firms are less willing to comply with tax laws when they perceive the influence over their government to be unfavorable to them or the result of an unfair policymaking process. Consistent with this argument, we find that firms evade more tax when other domestic firms have more perceived influence over domestic government policymaking. This suggests a potential negative externality of lobbying: higher tax evasion by other firms. However, government effectiveness or lack of corruption eliminates the positive relation between evasion and perceived influence over policymaking. Our results suggest that limiting domestic firms' influence over policymaking could help governments decrease tax evasion.
\end{abstract}




\section{INTRODUCTION}

Tax evasion continues to gain public and governmental attention (Beck, Lin, and Ma 2014; Hanlon, Maydew, and Thornock 2015; Slemrod 2018), especially following the 2008 financial crisis and the subsequent criticism of firms not paying their "fair share" of taxes (e.g., Starbucks in the UK; Barford and Holt 2013). Tax evasion is particularly problematic in developing countries, the subject of our study, and has especially negative effects in those countries (Bearak 2016). However, tax evasion is also an issue in developed countries such as the U.S.; the Internal Revenue Service (IRS) estimates that lost revenue from underreporting of income (i.e., tax evasion) exceeds $\$ 350$ billion annually, with a non-compliance rate of 18.3 percent. ${ }^{1}$ That is, 18.3 percent of the tax that should be collected is not collected because of evasion. With governments world-wide facing budgetary issues, understanding tax evasion is particularly important due to the economic significance of the lost governmental revenue involved.

In this study, we explore an important but understudied aspect of tax evasion: firms' relation with the government. Specifically, we explore how firms' perceptions of who influences domestic government policymaking affects firms' decisions to evade taxes. ${ }^{2}$ We identify three separate and distinct groups that firms can perceive as influencing policymaking: domestic firms (including the taxpaying firm and other domestic firms), foreign firms, and international development agencies/foreign governments. We propose that this perceived influence affects firms' tax compliance decisions. ${ }^{3}$ Existing literature on non-deterrence aspects of tax compliance

\footnotetext{
${ }^{1}$ https://www.irs.gov/PUP/newsroom/tax\%20gap\%20estimates\%20for\%202008\%20through\%202010.pdf, accessed April 10, 2017.

${ }^{2}$ Consistent with recent research (e.g., Bertrand and Schoar 2003), we acknowledge that managers, not firms, make the firms' decisions. Despite this, for ease of exposition throughout the paper we refer to firms' decisions, rather than the decisions of the firms' managers.

${ }^{3}$ Prior tax evasion research often focuses on individual taxpayers (e.g., Allingham and Sandmo 1972). However, Slemrod (2018) points out that the majority of individuals' tax evasion stems from the underreporting of business
} 
often focuses on individual taxpayers' attitudes and perceptions regarding other taxpayers

(Slemrod 2018). ${ }^{4}$ However, tax compliance may also be a function of firms' attitudes towards the government and the perceived fairness of the tax system (e.g., Levi 1989; Alm, Jackson, and McKee 1992a; Bordignon 1993; Braithwaite and Levi 1998). Thus, we extend this literature to incorporate the role of perceived influence over government policymaking on tax evasion.

Consistent with Tyler (1997, 2006) and Levi (1998), we conjecture that taxpayers are less likely to pay tax when they view government policymaking as legitimate, trustworthy, and following a fair process (i.e., procedural fairness). If procedural fairness decreases (or increases) due to other parties' influence on policymaking, we should observe an effect on tax evasion. Perceived influence on government policymaking includes influence over tax policies as well as non-tax policies such as those regarding expenditures of tax revenue, with influence over either type of policy potentially affecting the procedural fairness of policymaking and thus tax evasion decisions. Moreover, the perceived influence over government policymaking and its effect on tax evasion may vary depending on the source of the influence. That is, whether firms perceive the influence to have a positive or negative effect may depend on who influences the government. ${ }^{5}$ How perceptions of influence over government policymaking affect tax evasion presents an important open empirical question, especially considering that the overall effect of the perceived

\footnotetext{
income in small businesses, which are the focus of our study. Thus, we refer to survey respondents in our sample as firms rather than individuals. Importantly, our sample contains a significant number of closely held firms (>60 percent of sample firms) where the survey respondent is likely the firm's majority (controlling) owner. Furthermore, even when a firm is not closely held, the manager's survey response reflects the manager's attitude towards tax evasion and the manager's personal tax evasion decisions, which are reflected in firm behaviors (Johnson, Kaufmann, McMillan and Woodruff 2000; Joulfaian 2000; Chyz 2013). See also Cen and Doukas (2018). ${ }^{4}$ Non-deterrence aspects of tax compliance include "behavioral" considerations such as intrinsic willingness to pay tax (see Slemrod (2018) and Alm (2019) for reviews) whereas deterrence aspects include items such as audits, penalties, and the probability of detection (Allingham and Sandmo 1972). Perceived influence over policymaking, as we study in this paper, is a non-deterrence aspect of tax compliance. The next section provides a more detailed discussion of both non-deterrence and deterrence models of tax compliance. Note that tax compliance and tax evasion are inverses (i.e., evasion equals non-compliance), and we use both terms in this paper.

${ }^{5}$ Frumin (2015), Helderman, Hsu, and Hamburger (2016), Kalla and Broockman (2016), and Brown and Huang (2017) show that government policy is subject to influence.
} 
fairness of the tax system on tax evasion is ambiguous (see Cowell 1990 for a review).

As is common in the tax evasion literature (e.g., Andreoni, Erard, and Feinstein 1998), we explore this question using a survey. Specifically, we obtain survey data covering 37 developing countries from the World Bank Private Enterprise Survey for years 2002 through 2004 (similar data is used, for example, in Beck et al. [2014]). Using this data, we measure firms' tax evasion as a function of the perceived influence over government policymaking by various separate and distinct groups including the taxpaying firm, other domestic firms, foreign firms, and international development agencies or foreign governments. This data enables us to understand the association, if any, between tax evasion decisions and perceived influence over government policymaking. Our sample consists of developing countries, which are most likely to suffer negative consequences from tax evasion (e.g., Bearak 2016). ${ }^{6}$ However, understanding the behavioral responses to perceived influence on policymaking, especially the influence of foreign entities, is increasingly important across all countries as globalization continues (see, e.g., Swanson [2016] for an example unrelated to tax evasion).

We acknowledge that survey data on tax evasion is often subject to self-reporting bias (Slemrod 2007). However, our survey has an advantage over some prior surveys in that, rather than asking about the firm's own (potentially incriminating) evasion, the survey asks about the firm's perception of the tax evasion of other local businesses in the industry to elicit more truthful responses. Prior literature suggests that one's perception of others' evasion is linked to one's own evasion (e.g., Sandmo 2005) and therefore generally uses this perception to proxy for

\footnotetext{
${ }^{6}$ For example, Brazilian firms created a large 'informal economy' to evade tax. The informal economy harms development by discouraging legitimate business while encouraging organized crime (Rapoza 2004). Further, the loss of governmental revenue leads to higher taxes, and thus more evasion, creating the need to devote significant portions of scarce government resources to combating evasion (Rapoza 2004; Soto 2012).
} 
a firm's own evasion (e.g., Beck et al. 2014). ${ }^{7}$ Our survey data, based on previously validated measures, enables us to assess the relation between firm-level tax evasion and perceived influence over policymaking.

We estimate empirical models regressing tax evasion on our measures of perceived influence as well as additional firm- and country-level measures that could affect our variables of interest, along with country and industry fixed effects. We find that, after considering all groups perceived to influence policy, only the perceived influence of other domestic firms on policymaking is associated with higher levels of tax evasion. Unfortunately, we cannot definitively conclude why other domestic firm's perceived influence on domestic policymaking has the strongest positive association with a firm's tax evasion, compared to the influence of the other groups we study. One potential explanation is that other domestic firms, potentially supporting their own special interests, are viewed by firms as the closest, most relevant competitors, leading firms to view this influence as the most detrimental to their own interests. Similarly, foreign interests could be viewed as too disperse to affect the firm directly.

We next examine whether our results differ based on the overall perceived quality (i.e., effectiveness) of the domestic government. If the domestic government is perceived to be effective, other parties' influence over policymaking should have less influence over tax evasion because taxpayers are more likely to trust the government's policymaking process. We find evidence consistent with this argument. Specifically, high domestic government effectiveness eliminates the positive association between the influence of other domestic firms and tax evasion that we find in our main tests. Similarly, low levels of corruption also eliminate the positive

\footnotetext{
${ }^{7}$ See the section 'Measurement of Tax Evasion' for additional discussion supporting the use of our tax evasion proxy. Prior literature also shows that public perceptions of the government are consistent with expert judgements (Svallfors 2013), suggesting that taxpayers' perceptions of influence over the government are credible indicators of actual influence.
} 
association between the influence of other domestic firms and tax evasion.

In sum, our results suggest that firms are less likely to evade tax when they view the process of policymaking as legitimate (e.g., Levi 1998; Tyler 2006), such as when the government is more effective or less corrupt. Firms are more likely to evade tax when they perceive influence over government policy to be in opposition to their own interests, such as when the influence arises from other domestic firms. This study contributes to the literature by exploring an important but understudied non-deterrence aspect of tax compliance: taxpayers' perception of who influences government policymaking. As globalization and perceived influence by certain groups on the political process increases, it is important to understand how these factors influence firms' willingness to evade tax. Because of limitations to deterrence models of tax evasion (see e.g., Alm, McClelland, and Schulze 1992b), Slemrod (2018) and Alm (2019) call for additional research to better understand non-deterrence explanations for tax compliance. Our study helps answer these calls.

In addition, our study contributes to the literature on firms' political connectedness and the effects of lobbying activities on firms' tax planning strategies (see Barrick and Brown (2018) for a review). While existing work focuses on firms' own political activities and tax compliance (e.g., Richter, Samphantharak, and Timmons 2009; Brown, Drake, and Wellman 2015; Meade and Li 2015; Kim and Zhang 2016; Barrick and Frischmann 2017; Baloria and Klassen 2018), we extend this literature by assessing how perceived influence over government activities from sources outside of the firm affects tax compliance. Our findings provide new evidence on a possible negative externality of political activities such as lobbying: domestic firms' lobbying activities may lead other firms to evade more tax in response.

From a policy perspective, our results suggest that governments should consider firms' 
perceptions of the various influences over the government's policymaking process when analyzing policies. We identify one cost of perceived influence over policymaking, additional tax evasion, though we acknowledge we are unable to identify other costs and benefits of these perceptions or of the influence itself. Broadly, however, accounting for the effect of perceptions in order to increase tax compliance is important in lowering the government's cost of raising revenue (e.g., Slemrod 2007, p. 40). Overall, our study indicates that perceived influence of different groups affects perceptions of procedural fairness differently. As levels of trust in governments and institutions sink to new lows (e.g., Norman 2016; El-Erian 2017; Verschoor 2018), it becomes increasingly important for governments to consider perceived influence over policymaking to understand any potential associated negative consequences (e.g., tax evasion).

Our paper is also related to the literature on the perceived inequality among taxpayers and parties that influence government policy. Several highly cited studies (see, e.g., Piketty and Saez (2014) and Piketty (2015), among many others) have led to numerous popular press articles (e.g., Goodwin 2017) and associated protests and movements (e.g., Occupy Wall Street) related to perceived increases in inequality. ${ }^{8}$ As perceived inequalities regarding which taxpayers pay their fair share of tax and which taxpayers influence policymaking increase (Slemrod 2018), it is also increasingly important to understand the consequences of such perceptions. Our results suggest that perceived inequalities regarding influence over government policymaking can affect firms' decision making, specifically tax evasion decisions.

We recognize that our study has several limitations. Like most archival data, survey data

\footnotetext{
${ }^{8} \mathrm{We}$ refer to perceived, rather than actual, increases in inequality because numerous studies dispute the methods and conclusions of the work by Piketty, Saez, and colleagues. See, e.g., Hagopian and Ohanian (2011), McCloskey (2014), Bricker, Henriques, Krimmel, and Sabelhaus (2016), Larrimore, Burkhauser, Auten, and Armour (2017), Geloso and Magness (2017), and Coibion, Gorodnichenko, and Koustas (2017). Exploring this debate is beyond the scope of this paper. Only perception is relevant in our setting (see Gimpelson and Treisman 2018).
} 
can suffer from endogeneity concerns. Specifically, government policies, including tax specific policies, are not necessarily randomly assigned and are affected by lobbying - that is, influence itself (e.g., Barrick and Brown 2018). In addition, like most empirical proxies, our measures of perceived government influence and tax evasion are imperfect. Because our survey data is purely observational, we are unable to draw strong causal inferences regarding the relation between influence over policymaking and tax evasion. Finally, our study focuses on tax evasion in developing countries, where the effects of evasion are particularly harmful, and complements work on evasion in developed countries (e.g., Alstadsæter, Johannesen, and Zucman 2017). However, we acknowledge our focus on developing countries potentially limits the generalizability of our findings to developed countries. Despite these limitations, our analyses on the relation between perceived influence over government policymaking and tax evasion provide a first glimpse into an understudied and important non-deterrence aspect of tax evasion.

\section{PRIOR LITERATURE AND HYPOTHESES}

A long line of literature examines the deterrence model of tax evasion presented by Allingham and Sandmo (1972). Their model proposes tax evasion is a function of the tax rate, the likelihood of being caught evading, and the expected penalty for evasion. Numerous empirical studies examine Allingham and Sandmo's (1972) deterrence model of evasion, finding some support of deterrence, but also mixed evidence (see, e.g., Kirchler, Hoelzl, and Wahl (2008) for a review emphasizing some of the mixed results). ${ }^{9}$ Despite some evidence supporting various aspects of the deterrence model, researchers also find the tax evasion decision to be much more complicated than just an economic cost-benefit tradeoff (e.g., Andreoni et al. 1998;

\footnotetext{
${ }^{9}$ For empirical support of Allingham and Sandmo's (1972) model, see: Klepper and Nagin (1989), Slemrod, Blumenthal, and Christian (2001), and Cabral, Kotsogiannis, and Myles (2015). However, evidence in this area is mixed, especially regarding taxpayer responses to actual audits (i.e., detection risk) and marginal tax rates (e.g., Clotfelter 1983; Feinstein 1991; DeBacker, Heim, Tran, and Yuskavage 2015a, b; Li, Pittman, and Wang 2018).
} 
Kirchler et al. 2008). Taxpayers maximize their own individual utility; however, they factor in personal beliefs and preferences such as behavioral, social, or tax morale considerations (e.g., Fortin, Lacroix, and Villeval 2007; Besley, Jensen, and Persson 2019; Brink and Porcano 2016; Kouamé 2017; Alm 2019). ${ }^{10}$ As a result, taxpayer behavior can be very heterogeneous across objectively similar taxpayers (e.g., Alm et al 1992b). ${ }^{11}$ However, like the deterrence literature, the literature on non-deterrence models of tax evasion is also somewhat mixed (e.g., Blumenthal, Christian, and Slemrod 2001; Torgler 2004).

Several recent studies show that non-deterrence attributes affect tax compliance decisions, raising the possibility that a non-deterrence attribute like perceived influence over policymaking could affect evasion. Broadly, prior research shows that ethics, social norms, and trust play a role in tax evasion decisions (e.g., Davis, Hecht, and Perkins 2003; Hasan, Hoi, Wui, and Zhang 2017; Henderson and Kaplan 2005; Blanthorne and Kaplan 2008; Bott, Cappelen, Sørensen, and Tungodden 2017; Kanagaretnam, Lee, Lim, and Lobo 2018). Further, Richardson (2006) finds that non-economic factors are more important determinants of evasion than economic determinants. Prior work most related to our paper finds that taxpayers are more likely to comply with tax laws when they believe they receive public goods for their taxes (Alm et al. 1992a, b; Bordignon 1993; see also Williamson 2017) and are less likely to comply when they believe government policy is wrong (Spicer and Lundstedt 1976; Andreoni et al. 1998; Stanley and Hartman 2016). Pommerehne and Weck-Hannemann (1996) and Frey (1997) find that stronger political participation rights reduce tax evasion. This work would suggest that perceived influence over government policy could reduce (increase) evasion if taxpayers view the influence

\footnotetext{
${ }^{10}$ See Zeckhauser (1986) for further discussion.

${ }^{11}$ For example, LaLumia and Sallee (2013) compare a subset of taxpayers who engaged in a known tax evasion practice to those who do not and find both groups face similar tax evasion incentives.
} 
as supporting (opposing) their interests. Relatedly, Webley, Robben, Elffers, and Hessing (1991), Torgler (2003), Svallfors (2013), and Cullen, Turner, and Washington (2018) find that attitudes toward the government affect tax evasion. However, some work finds no evidence that perceived inequities in the tax system affect evasion (see Cowell 1990, Chapter 6 for a review), suggesting that perceived influence over policymaking may not affect evasion. ${ }^{12}$

More broadly, Besley and Persson (2009) describe how a government must build capacity to tax through common interests in public goods such as military spending (see also Daunton (1998), Levi (1998), and Robbins and Kiser (2018)). Casaburi and Troiano (2016) show that tax enforcement actions by the government are viewed more favorably in areas with more efficient public good provision. Therefore, when the government is perceived to operate inefficiently or without taxpayers' best interest in mind, the capacity to tax may decrease (Levi 1998). We extend this argument to the policymaking process of the government. That is, procedural fairness of a government affects compliance (e.g., Tyler 1997). If influence over policymaking affects procedural fairness of the government, we expect influence over policymaking to affect tax evasion decisions. If firms perceive that other parties influence the government in an unfair manner, or to create regulations at odds with the firms' own preferences, then we expect that such firms will choose to evade more tax. In contrast, if firms view influence by certain parties as beneficial to the government, for example, by increasing efficiency or procedural fairness, external influence may reduce evasion.

As previously mentioned, the relation between perceived influence over government

\footnotetext{
${ }^{12}$ Note that we study perceived influence over all policymaking, not only tax-related policymaking. Prior work also finds that initially compliant taxpayers become non-compliant as they learn about non-compliance of other taxpayers. That is, as compliant taxpayers see that they are being taken advantage of by non-compliant taxpayers, the share of compliant taxpayers will shrink (Pommerehne, Hart, and Frey 1994; Sandmo 2005; Slemrod 2007; Garcia et al. 2018). To the extent that taxpayers view entities influencing the government as taking advantage of the taxpayers, evasion is likely to increase.
} 
policymaking and tax evasion likely varies based on the source of the influence. We examine how evasion varies with a firm's perception of the influence of the taxpaying firm itself, other domestic firms, foreign firms, and international development agencies or foreign governments. Ex ante, it is unclear which of these groups is most likely to affect firms' tax evasion decisions, or the direction of the effect. We discuss each source of influence separately below. ${ }^{13}$

First, a firm itself can influence policy through techniques such as lobbying, providing Congressional testimony, or writing comment letters on proposed regulations. Obviously these efforts will be in the firm's best interests. However, the firm is unlikely to always succeed in its efforts to influence policy, potentially limiting the firm's perception of its own influence over policymaking. Finding a positive relation between a firm's own influence on government policymaking and tax evasion suggests that firms evade more tax because their influence over government policymaking reduces their need to comply with existing law (i.e., regulatory capture). Finding a negative relation could suggest that a firm is more likely to comply in order to maintain a good reputation and/or relationship, and therefore influence, with the government. A negative relation could also indicate a decreased incentive to evade tax because the firm's influence results in a situation where complying with regulations is in the firm's best interest or because the firm agrees with the government policies they helped shape. As such, we present the following hypothesis, in the null form, for the relation between a firm's own influence and tax evasion.

H1a: A firm's view of its own influence on policy does not affect tax evasion.

\footnotetext{
${ }^{13}$ Hillman, Keim, and Schuler (2004) provide a detailed review of different types of political activity firms can undertake. However, each activity has the same intended outcome of influencing policy. A discussion of the types of political activity is beyond the scope of our paper.
} 
Other domestic firms can likely influence policymaking in the same ways as the firm itself. However, these influences may or may not be in the best interest of the firm itself. As such, the firm could view lobbying by other domestic firms as complementary to the firm's interest or as substituting for the firm's interest (e.g., when the firm's preferred policy "loses" to another policy). Foreign firms can also engage in similar political activity but are less likely to engage in large scale lobbying activities or in testifying to Congress (Hillman et al. 2004). Further, foreign firms may have more disperse interests than domestic firms. As such, the firm itself may feel less threatened by foreign influence. On the other hand, because we study developing countries, foreign firms may be more sophisticated or better capitalized, leading to more negative views of this source of influence. Finally, international development agencies and foreign governments likely have more direct and official channels to influence the domestic government. As such, firms may view these entities as more powerful than other (foreign or domestic) firms. However, it is unclear ex ante whether firms are likely to view this influence as positive (e.g., improving overall government policy) or negative (e.g., supporting foreign interests at the expense of domestic firms).

Finding a positive relation between perceived influence of other groups (other domestic firms, foreign firms, or international development agencies/foreign governments) and tax evasion indicates that firms view the influence of the respective group as reducing the fairness of policy, reducing firms' willingness to pay taxes to fund those policies. Finding a negative relation between any of these groups' influence and tax evasion indicates that firms view the influence of the respective group as improving the quality of the government and thus benefiting the firm either directly through improved tax policy or indirectly via government spending, beneficial government policies, or improved efficiency. Because the influence of each of these groups is 
distinct from the other groups as discussed above, ex ante it is unclear whether some, all, or none of these groups' influence will affect tax evasion decisions. The direction of the effect, if any, of the perceived influence of these groups could also differ across the separate and distinct groups. However, we are unable to make ex ante predictions for differences across groups. Therefore, we present our hypotheses related to the influence of these groups separately in the null form.

H1b: A firm's view of other domestic firms' influence on policy does not affect tax evasion.

H1c: A firm's view of foreign firms' influence on policy does not affect tax evasion.

H1d: A firm's view of international development agencies' and foreign governments' influence on policy does not affect tax evasion.

\section{SAMPLE SELECTION AND VARIABLES}

\section{Sample Selection}

Our sample starts with a dataset of confidential firm-level survey responses provided by the World Bank that includes information from the World Bank's Private Enterprise Surveys for 2002-2004. ${ }^{14}$ The World Bank’s Private Enterprise Survey anonymously surveys business owners and top-level managers from various industries in developing countries with the intent to "better understand conditions in the local investment climate and how they affect firm-level productivity." The survey's stated goal (also conveyed to participants) is to "advise government on ways to change policies that hinder private establishments like yours and to develop new policies and programs that support productivity growth" (The World Bank, n.d.).

The survey is a written survey conducted in a room that contains both a World Bank representative as well as a member of the local private sector such as the head of the chamber of

\footnotetext{
14 The World Bank Private Enterprise Survey data was accessed by one of the authors through a confidentiality agreement with the World Bank.
} 
commerce or industry association. The World Bank representative makes sure the survey is administered consistently across countries and the local private sector representative is there to engender the respondent's trust. Government officials and financial institutions are not involved in the surveys and neither government officials nor financial institutions are ever provided with raw data or any other information that will allow them to identify the responses of individual firms (Beck et al. 2014; Williams 2017). ${ }^{15}$ Participants in the study are promised complete and strict confidentiality both personally and for their firms (Beck et al. 2014; Williams 2017).

When conducting the survey, a uniform sampling methodology and standardized survey instruments are used to minimize measurement error and to yield data that are comparable across countries (Williams 2017). Sample sizes are between approximately 250 and 1,500 companies per country and data are collected using simple random or randomly stratified sampling (The World Bank, n.d.). The survey involves questions on many firm characteristics and the question on tax evasion, discussed in the next section, occurs near the end of the survey, after the surveyors and the respondents have had time to develop mutual trust and understanding.

Importantly, as noted in Beck et al. (2014) and Williams (2017), firm responses to the survey are accurate and reliable; several research papers verify that firm responses to World Bank surveys are closely and directly related to measurable outcomes in corruption, expropriation, protection of property rights, corporate financing, operating obstacles, tax evasion, investment, performance, and growth. ${ }^{16}$ The World Bank also uses its survey data in conducting its own research and influencing policy. ${ }^{17}$

\footnotetext{
${ }^{15}$ Entities that are 100 percent owned by local or national governments are ineligible to participate in the World Bank's Enterprise Survey (The World Bank, n.d.).

${ }^{16}$ See, for example: Johnson et al. 2000; Djankov, La Porta, Lopez-de-Silanes, and Shleifer 2003; Acemoglu and Johnson 2005; Beck, Demirguc-Kunt, and Maksimovic 2005; Ayyagari, Demirguc-Kunt, and Maksimovic 2008, 2010; Barth, Lin, Lin, and Song 2009; Beck et al. 2014.

${ }^{17}$ https://www.worldbank.org/en/research
} 
We combine this World Bank data with several publicly available datasets including the country-level corruption and rule of law indices developed by Kaufman, Kraay, and Mastruzzi (2011), the Standardized World Income Inequality Database from Solt (2016), and the World Bank Development Indicators Database. We exclude observations with missing information, which leaves us with a final merged sample consisting of 7,347 firm-year observations from 37 countries. Table 1 details our sample selection process. ${ }^{18}$

\section{<Insert Table 1 here>}

\section{Measurement of Tax Evasion}

Following World Bank analysts, as well as prior research (e.g., Beck et al. 2014; Williams 2017), we measure tax evasion using firm responses to the survey question "Recognizing the difficulties many enterprises face in fully complying with taxes and regulations, what percentage of total sales would you estimate the typical establishment in your area of activity reports for tax purposes?" Following well-established survey techniques, the World Bank intentionally words the question indirectly to solicit more truthful responses.

One concern is that the indirect nature of the question on tax evasion could result in measurement error as answers may be representative of perceived industry averages rather than the firm's own behavior. However, there are several reasons that this potential measurement error will not bias our results (Beck et al. 2014; Williams 2017). First, there is substantial within country-industry variation in the tax evasion response suggesting that firms respond to the question based on their own behavior rather than perceived industry behavior. ${ }^{19}$ Second, as previously mentioned, individual managers' responses to the survey regarding tax evasion can be

\footnotetext{
${ }^{18}$ Our sample differs from the sample used in Beck et al. (2014). Unlike Beck et al. (2014), we study the perceptions of influence over government policymaking, which limits our sample to only firms responding to these questions.

${ }^{19}$ As we discuss later, we include country and industry fixed effects in our model. Thus, our regression results take advantage of and are based on the variation in the tax evasion response within country and industry.
} 
interpreted as firms' own tax evasion (Johnson et al. 2000; Joulfaian 2000; Chyz 2013; Beck et al. 2014). Third, Beck et al. (2014) find a high correlation between the survey's tax evasion measure and the tax evasion index developed by the World Competitiveness Yearbook. Finally, as previously discussed, prior research finds that responses to World Bank surveys are directly associated with measurable outcomes in several areas including corruption, expropriation, protection of property rights, corporate financing, operating obstacles, tax evasion, investment, performance, and growth (Beck et al. 2014).

We utilize firms' responses to the World Bank surveys to create our variable of interest related to firm-level tax evasion, Tax Evasion Ratio. Tax Evasion Ratio is calculated as one minus the answered numerical response to the survey question on tax evasion. That is, tax evasion equals zero if the firm answers that 100 percent of sales are reported for tax purposes. Table 2, Panel A, reports the mean Tax Evasion Ratio for each country in our sample. There is large variation in the Tax Evasion Ratio across countries. The mean Tax Evasion Ratio per country ranges from about $7.3 \%$ in Sri Lanka to $79.3 \%$ in Senegal. We utilize the variation in firm-level tax evasion in our tests examining the relation between perceived influence over tax laws and tax evasion. ${ }^{20}$ Note that, because we base our measure on unreported sales, our proxy directly relates to our construct of interest, tax evasion, because unreported sales generally indicate illegal tax evasion, although we acknowledge that a limitation of this measure is the possibility that some countries may exempt certain sales from tax reporting requirements.

<Insert Table 2 here>

\footnotetext{
${ }^{20}$ We note that over 18 percent of our observations are from Brazil. To ensure our findings are not driven by these firms, we analyze our baseline models excluding observations from Brazil and find results consistent with those presented in the next section.
} 


\section{Measurement of Perceptions of Influence over Laws and Regulations}

Our measure of firms' perceptions of influence over laws and regulations come directly from questions asked of participants during the World Bank survey. Specifically, survey participants are asked "How much influence do you think the following groups actually had on recently enacted national laws and regulations that have a substantial impact on your business?" For each group, the amount of influence is either no impact (0), minor influence (1), moderate influence (2), major influence (3), or decisive influence (4). We use the firm's responses to this question related to "your firm" (Own Firm Influence), "other domestic firms" (Other Domestic Firms' Influence), “foreign firms” (Foreign Firms' Influence), and “international development agencies or foreign governments" (Intl. Development Agency/Foreign Governments' Influence) to form our variables of interest relating to various parties' influence over laws and regulations.

Table 2, Panel A, presents the average for each measure of perceived influence for each country in our sample. Firms generally perceive their own influence over government policies to fall between no influence (coded zero) and minor influence (coded one), although this varies from almost zero (Senegal) to nearly moderate influence (coded two; Tanzania). Perceived influence is higher for other domestic firms, foreign firms, and foreign development agencies, with the average level falling just above a minor influence (coded one). Kenya, Tanzania, Uganda, and Zambia tend to have high scores across these three measures of influence, as might be expected given the foreign aid targeted to these countries, with influence rated generally between moderate (coded two) and major (coded three).

Table 2, Panel B, presents the average of Tax Evasion Ratio and each of the four variables of perceived influence over government policymaking by industry. We find significant variation in the level of tax evasion across industries, with the highest level of evasion in the 
agricultural industry (48.8 percent) and the lowest level in the telecommunications industry (7.4 percent). We also find univariate evidence that firms operating in the electronics and auto industry have above average perceived levels of influence across all four measures of influence. However, these industries have average levels of tax evasion, providing little insight on our hypotheses. Therefore, we draw our main inferences from the multivariate regressions in the next section. Overall, Table 2, Panel B shows that variation exists across industries, yet the variation is smaller than the variation across countries presented in Panel A. Our empirical analyses include both country and industry fixed effects to address the differences in tax evasion and perceived influence across countries and industries.

\section{RESEARCH DESIGN AND RESULTS}

\section{Research Design}

To investigate the relation between perceptions of various parties' influence over local laws and regulations and the extent of firm-level tax evasion, we run several empirical tests. We begin with the following base regression:

Tax Evasion Ratio ${ }_{i t}=\alpha+\beta$ Influence_Measures $i t+\gamma$ Controls ${ }_{i t}+\mu$ Industry Fixed Effects $i_{+}+$ $\delta$ Country Fixed Effects $i+\mathcal{E}_{\text {it }}$

Tax Evasion Ratio, as previously defined and as reported by firm $i$ in year $t$, is the dependent variable. Because our dependent variable, Tax Evasion Ratio, is constrained between 0 and 1, we use Tobit regression models. ${ }^{21}$ Influence_Measures takes the form of one or all of our measures of the firm's perception of various parties' influence over local laws and regulations (Own Firm

\footnotetext{
${ }^{21}$ Our dependent variable, Tax Evasion Ratio, is by construction bounded at zero and one, a situation Wooldridge (2010) refers to as a 'corner solution outcome.' Such an outcome is treated similarly to a 'censored response' dependent variable, where the use of a Tobit regression model is most appropriate (Wooldridge 2010). Tobit models are commonly used in accounting research for corner solution outcomes (e.g., impairment percentage; Stein 2018). For robustness we also estimate our empirical model using ordinary least squares (OLS) and find results consistent with the Tobit model.
} 
Influence; Other Domestic Firms' Influence; Foreign Firms' Influence; or Intl. Development Agency/Foreign Governments' Influence).

Our model includes several firm-level control variables that could potentially be linked to both tax evasion and the firm's perception of various parties' influence over laws and regulation. We control for the percent of the firm owned by foreign investors (\% Foreign Ownership) to account for the possibility that foreign ownership affects tax evasion decisions. On one hand, foreign-owned firms could have less connection to the public goods provided by the government leading to a higher level of tax evasion. Alternatively, because we study a sample of developing countries, foreign owners may be from developed countries and as such provide more stringent manager oversight, preventing risky tax evasion or ensuring their investee firms appear on their "best behavior" to reduce expropriation concerns.

We control for the extent to which the corporate tax rate affects the decision to evade tax (Allingham and Sandmo 1972) by including the maximum statutory corporate tax rate (Statutory Corporate Tax Rate) in each country. ${ }^{22}$ We control for whether the firm indicates that its financial statements are externally audited (Externally Audited Financial Statements) to account for the effect of additional oversight on tax evasion decisions (Beck et al. 2014). We also include a variable capturing whether the firm is an exporter (Firm is an Exporter) because prior work finds that firms evade tariffs (a type of tax) (e.g., Fisman and Wei 2004; Mishra, Subramanian, and Topalova 2008), which could affect firms' decisions to evade income taxes. We control for

\footnotetext{
${ }^{22} \mathrm{We}$ acknowledge that it may be the perception of the tax rate that influences tax evasion, rather than the rate itself. Additionally, at least some of the firms in our study likely have marginal tax rates that differ from the maximum corporate tax rate. As such, we re-estimate our main model (Table 5: Panel A) replacing the maximum statutory corporate tax rate with a variable derived from the World Bank survey that captures each firm's perception of whether the firm's tax rate is an obstacle to business (untabulated). We continue to include country fixed effects, which capture country-level items like the maximum statutory corporate tax rate. All results presented in Table 5, Panel A are robust to this alternative model, except that when estimated individually, the influence of international development agencies/foreign governments is no longer significantly related to tax evasion at conventional levels ( $\mathrm{t}$ statistic 1.46 , column 4$)$.
} 
firm age (Log(Firm Age)) and firm size (Log(\# of Firm Employees)) to account for differences in the opportunities and incentives to evade tax for larger and older firms as compared to smaller and younger firms. ${ }^{23}$ Finally, we control for whether the firm is privately owned (Privately Owned Firm) to account for differences in tax strategies for these firms (e.g., Chen, Chen, Cheng, and Shevlin 2010; Badertscher, Katz, and Rego 2013).

We also include several country-level controls in our baseline model to account for observable, time-varying differences across countries. First, we control for time-varying differences in country-level institutions through the inclusion of country-year measures of control of corruption (Control of Corruption), rule of law (Rule of Law), and government effectiveness (Government Effectiveness), all from the Kaufmann et al. (2011) indices. We also include per capita GDP ( $\log ($ GDP Per Capita $))$ to control for economic development. Appendix A presents detailed information on the source and definition of each variable. Finally, we include country $(\delta i)$ and industry $\left(\mu_{i}\right)$ fixed effects to account for unobservable time-invariant differences across countries and industries, respectively, that could influence the tax evasion decision. ${ }^{24}$

Table 3 presents summary statistics for our variables. Similar to prior research, such as Beck et al. (2014), we find a mean Tax Evasion Ratio of 0.225 suggesting that the average firm

\footnotetext{
${ }^{23}$ We follow prior research and control for size by using the firm's number of employees because currency units and their relative purchasing parity vary across countries.

${ }^{24}$ We tabulate estimation results including the country-level control variables for only our baseline model, presented in Table 5, because variation in tax evasion explained by these additional country-level control variables is largely subsumed by the inclusion of country fixed effects. Further, we note that the inclusion of both country-level controls and country fixed effects leads to multicollinearity issues in our empirical models. Importantly, we find that the coefficients and t-statistics related to the perceived influence variables in our regressions are similar whether these country-level controls are included or excluded. Including these controls leads to only a marginal increase in explanatory power, as compared to excluding them, with an increase in the pseudo R-squared of only $0.005(0.234$ versus 0.229 ). In untabulated tests, we examine the effects of including both industry and country fixed effects on the explanatory power of our model. We find that including only industry fixed effects results in a pseudo R-squared of 0.051 . Adding country fixed effects significantly increases the explanatory power, with pseudo R-squared increasing by 0.145 (from 0.051 to 0.196 ). Due to the structure of the World Bank's survey procedures, firms in most countries in our sample answer the question on influence over policymaking in only one year. Thus, we do not include year fixed effects.
} 
in the sample fails to report approximately 23 percent of its sales to the tax authority. ${ }^{25} \mathrm{We}$ find that the average firm in our sample views its own influence on laws and regulation (Own Firm Influence) to be about halfway between no influence (value of zero) and minor influence (value of one). In contrast, the average firm in our sample views the impact of other domestic firms, foreign firms, and international development agencies/foreign governments on laws and regulations to be somewhere between a minor influence (value of one) and a moderate influence (value of two). We note that there is substantial variation in all three of these measures, as each measure has a minimum of 0 (no influence) and a maximum of 4 (decisive influence).

$<$ Insert Table 3 here $>$

\section{Preliminary Analysis}

To gain initial insight into the effect of perceived government influence on tax evasion, we analyze the correlations between our variable of interest, Tax Evasion Ratio, and firms' perceptions of various parties' influence over local laws and regulations. The correlations are presented in Table 4, with bolded coefficients indicating significance at the 10 percent level. We observe a significant positive correlation between the decision to evade tax and the influence over government policy from organizations external to the firm surveyed. More specifically, as the perceived influence from other domestic firms $(\rho=0.077)$, foreign firms $(\rho=0.105)$, or international development agencies and foreign governments $(\rho=0.029)$ increases, so does the level of tax evasion. We also find a significant positive correlation between a firm's tax evasion and its perception of its own influence over government policy $(\rho=0.020)$. Thus, our initial findings suggest influence over government policy affects firms' tax evasion choices. However, we caution that these univariate correlations do not control for potentially confounding relations

\footnotetext{
${ }^{25}$ While the United States is not in our sample, this 23 percent evasion rate somewhat similar to the 18.3 percent non-compliance rate estimated by the IRS and discussed earlier.
} 
among the measures of interest, or other variables, and thus we defer drawing conclusions to our multivariate regression analysis.

We also find a positive and significant correlation between both firm age $(\rho=0.103)$ and firm size (i.e., the number of firm employees) $(\rho=0.180)$ and the perceived influence the firm itself has over government policymaking. This suggests larger, older firms are more likely to exhibit influence over domestic government policymaking consistent with larger firms having more bargaining power or economic sway (Barrick and Brown 2018). We also observe a significantly positive correlation between the firm's perception of its own influence and its perception of the influence of other domestic firms $(\rho=0.381)$ and foreign firms $(\rho=0.137)$. Further, we find a positive and significant correlation between the perceived influence of other domestic firms and the perceived influence of both foreign firms $(\rho=0.474)$ and foreign governments or development agencies $(\rho=0.205)$. This suggests that perceptions of influence should be examined in conjunction with one another, in addition to separately.

\section{$<$ Insert Table 4 here $>$}

\section{Multivariate Regressions}

Our results to this point offer preliminary evidence that a firm's perception of who influences government policy can play a significant role in the decision to evade taxes. However, there are a number of additional factors that may influence this decision, such as other firm characteristics, macroeconomic trends, and additional country-, industry-, or government-related factors. Thus, we perform multivariate regressions including variables that capture differences in firms' tax evasion decisions that may be unrelated to perceived influence on the government.

Table 5, Panel A, presents our main multivariate analysis. Columns 1 through 4 present our estimations that include Own Firm Influence, Other Domestic Firms' Influence, Foreign 
Firms' Influence, and Intl. Development Agency/Foreign Governments' Influence, respectively, along with other firm, government, and macroeconomic controls as defined in Appendix A. We find that the perceived influence of other domestic firms (column 2, coefficient of $0.022, \mathrm{t}$ statistic of 2.62), foreign firms (column 3, coefficient of 0.014, t-statistic of 3.33), and international development agencies and foreign governments (column 4 , coefficient of 0.011 , tstatistic of 2.28) are each positively associated with tax evasion. ${ }^{26}$ These results reject our null hypotheses $1 \mathrm{~b}, 1 \mathrm{c}$ and $1 \mathrm{~d}$. This provides some very limited evidence that taxpayers view external influence on government policymaking from sources other than their own firm as reducing procedural fairness in government policymaking, increasing taxpayers' willingness to evade tax. This also indicates a possible costly externality of political lobbying activity: increased evasion by other firms. In contrast, we find no evidence that the firm's perception of its own influence on laws and regulations is associated with tax evasion (column 1, t-statistic 0.60 ).

One concern with these results is that influence on policy does not happen in isolation as indicated by the correlations presented in Table 4 - many parties typically influence a particular law or regulation. Therefore, to better isolate which group's influence over government policy most affects a firm's tax evasion decision, we estimate a fifth model that includes all possible groups to capture the simultaneous influence of each group. We present the results from this estimation in column 5 of Table 5, Panel A.

We find that after including controls and the perceived influence over government policy from multiple groups, tax evasion continues to be significantly positively associated with the

\footnotetext{
${ }^{26} \mathrm{We}$ acknowledge that the significant positive association between international development agencies and foreign governments and tax evasion may be subject to bias due to the survey administrator, the World Bank, being a major foreign development agency. However, we believe any such bias would be against our findings because development agencies are unlikely to intentionally elicit responses indicating that they are associated with increased tax evasion. Further, as discussed previously, survey respondents answer survey questions with strict anonymity using indirect questioning, which alleviates some concern regarding this potential bias.
} 
perceived government influence of other domestic firms with a coefficient of 0.019 and a tstatistic of 2.06 (rejecting null hypothesis 1b). Economically, a one-unit increase in the perceived influence of other domestic firms (approximately one standard deviation) is associated with an increase in tax evasion of about 8.4 percent. ${ }^{27}$ This represents an economically significant decrease in the amount of sales reported to taxing authorities. This finding suggests that, after accounting for perceived influence of all four sources of influence that we examine, only the perception of other domestic firms influencing government policymaking is associated with a decrease in tax compliance, perhaps due to its effect on perceived procedural fairness.

To further account for additional government and macroeconomic factors that can influence tax evasion decisions, we estimate our baseline model including the following countrylevel control variables defined in Appendix A: Control of Corruption, Rule of Law, Government Effectiveness, and $\log ($ GDP per Capita). Panel B of Table 5 presents these results, which are nearly identical to the results presented in Panel A. It is important to note that because we include country fixed effects in our Panel B estimation, in addition to these country-specific characteristics, variance inflation factors (VIFs) from this regression estimation are higher than recommended levels. Therefore, throughout the remainder of the paper we exclude Control of Corruption, Rule of Law, Government Effectiveness, and Log(GDP per Capita) from our analysis to avoid multicollinearity concerns in our empirical estimations. ${ }^{28}$

$<$ Insert Table 5 here $>$

\footnotetext{
${ }^{27}$ Coefficient of 0.019 on Other Domestic Firms' Influence on Laws scaled by mean Tax Evasion Ratio of 0.225 equals approximately 0.084 .

${ }^{28}$ Inferences from the results presented throughout the remainder of the paper are consistent if we ignore these multicollinearity issues and include all country-level variables in our empirical estimations.
} 


\section{Additional Analysis: Government Effectiveness}

As noted above, we argue and find that certain parties' influence on government policymaking can make taxpayers view the policymaking process as less fair. Specifically, we find that the influence of other domestic firms appears to lower taxpayers' perceptions of government quality (i.e., procedural fairness), increasing tax evasion. Consistent with this argument, if taxpayers already perceive the government as high quality, we expect perceived influence over the government will have less effect on tax evasion. That is, we expect that higher perceived government effectiveness will offset, in whole or in part, any effect of the influence of other parties. In order to test this, we interact the perceived influence of each party (the firm, other domestic firms, foreign firms, and international development agencies/foreign governments) with a variable capturing high levels of government effectiveness. We define High Government Effectiveness as an indicator variable equal to one for countries with a Government Effectiveness measure above the sample median, and zero otherwise. Table 6, columns 1 through 4, presents our results when interacting High Government Effectiveness with the influence of each party separately. Similar to our baseline results, column 5 presents the results when including all measures of influence and each of their interactions with our government effectiveness measure.

\section{$<$ Insert Table 6 here $>$}

We find that the results for the main effects of influence (when government effectiveness is low) are consistent with the previous results presented in Table 5. Other domestic firm influence, alone (column 2, coefficient of 0.029, t-statistic of 4.23) or combined with all influence simultaneously (column 5 , coefficient of 0.027 , t-statistic of 3.48 ), is positively associated with tax evasion. However, in column 2 (5), the interaction between other domestic 
firm influence and government effectiveness is negative yet insignificant with a t-statistic of 0.97 (-1.07). We conduct an F-test and find that for both columns 2 and 5, the sum of the coefficients on the main effect and interaction term (Other Domestic Firms' Influence on Laws + High Gov. Effectiveness*Other Domestic Firms' Influence on Laws) is not significantly different from zero (untabulated). Thus, as expected, having an effective government fully mitigates the association between perceived influence over policymaking and tax evasion.

As an additional test of whether government effectiveness attenuates the association between perceived influence and tax evasion, we use an alternative measure of government effectiveness based on the level of government corruption. Similar to our prior test, we expect that lower levels of government corruption will reduce the association between influence over government policymaking and tax evasion. We identify the level of corruption in a country using the Corruption Perceptions Index (CPI) constructed by Transparency International. CPI is an index, between 0 and 100, based on the 'perceived levels of public sector corruption according to experts and businesspeople' (Transparency International, n.d.). The higher a country's CPI, the lower the level of corruption. Using the CPI index, we construct the variable High Anti-CPI, which represents countries with the least amount of government corruption. Specifically, High Anti-CPI takes a value of one for all countries above the median in terms of the CPI and zero for countries below the median. We then interact this measure of anti-corruption with our measures of influence over policymaking and re-estimate our empirical models. Table 7 presents the results for own firm's influence (column 1), other domestic firm's influence (column 2), foreign firm's influence (column 3), and international development agencies and foreign government's influence (column 4) separately, with column 5 presenting the results when including all 
influence measures combined. ${ }^{29}$

Results are generally consistent with our previous results using High Gov. Effectiveness. We find other domestic firm's influence has a positive (column 2, coefficient of 0.024 , t-statistic 3.71; column 5, coefficient of 0.17 , t-statistic of 2.56) association with tax evasion in countries that have a higher level of corruption. Similar to the results in Table 6, F-tests (untabulated) show that there is no association between other domestic firm's influence and tax evasion for firms in low-corruption countries. Unlike the results in Table 6, however, we find that the perceived influence of international development agencies and foreign governments (column 4) is no longer significantly associated with tax evasion when separately estimated (t-statistic of 1.02). Interestingly, we find some evidence that firms own perceived influence over government policymaking is associated with more tax evasion when government corruption is high (column 1 , coefficient of 0.020 and t-statistic of 1.86), but only when we do not control for the other groups that can influence policymaking. This provides very limited evidence that firms with perceived political connections view the cost of tax evasion to be relatively low, consistent with Kim and Zhang (2016), but only in corrupt countries in our setting. In sum, these results suggest that while the perceived influence of other domestic firms on government policymaking is associated with higher tax evasion, this effect does not exist when the firms' government is perceived as more effective or less corrupt.

$<$ Insert Table 7 here $>$

\footnotetext{
${ }^{29}$ The CPI data is only available for about 82 percent of our sample, resulting in fewer observations in Table 7 than other tables.
} 


\section{Additional Analysis: Statutory Tax Rates}

As an additional analysis, we assess whether the relation between tax evasion and influence over government policymaking is affected by tax rates. Theoretical literature suggests tax evasion is affected by the statutory tax rate, yet the direction of the effect depends upon taxpayer characteristics (Allingham and Sandmo 1972, Yitzhaki 1974). Empirical literature is similarly mixed on the relation between tax evasion and tax rates (e.g., Clotfelter 1983 versus Feinstein 1991; see Alm 2019 for a review). The correlations in Table 4 provide evidence suggesting a significantly positive relation between Tax Evasion Ratio and Statutory Corporate Tax Rate, as well as a significant and positive association between each of our measures of perceived influence and the statutory corporate tax rate. Thus, we explore whether and to what extent the association between tax evasion and government influence differs based on the existing statutory tax rate.

To assess the possibility that the perceived influence on government policymaking and the statutory tax rate collectively affect tax compliance decisions, we estimate an augmented baseline model by including an interaction term for high statutory tax rate jurisdictions with each measure of perceived government influence separately, and then with all influence measures combined. We construct High STR, which is an indicator variable taking the value of 1 for countries that have an above the sample median statutory tax rate and 0 otherwise. Estimating our augmented model with these interaction terms (untabulated), we find evidence suggesting firms are more willing to pay taxes when both the statutory tax rate is high and they believe they have influence over government's policymaking (negative and significant coefficient on High STR * Own Firm Influence). In contrast, none of the other interactions of High STR and the influence variables are significant at conventional levels. We interpret this result as suggesting 
that firms are more likely to comply with more burdensome (in terms of rate) tax laws when they perceive government influence to be in alignment with their own interests.

\section{CONCLUSION}

Tax compliance and tax evasion have puzzled researchers for decades. As governments face budgetary issues and the perceived inequality in both income and taxes increase, understanding tax evasion is increasingly important. We explore an understudied area of tax evasion, namely a non-deterrence explanation for taxpayers' tax evasion decisions. Specifically, we argue that taxpayers' perceptions of who influences government policymaking alters firms' view of the procedural fairness of the tax system, which affects the tax evasion decision. We specifically examine the perceived influence of four distinct groups over domestic government policy - the firm itself, other domestic firms, other foreign firms, and international development agencies/foreign governments - and the effect of this influence on tax compliance decisions.

We find that firms evade more tax when other domestic firms are perceived to have more influence over government policy. This suggests that the perceived influence of other domestic firms over policymaking leads domestic taxpaying firms to view the policymaking process as less fair. As such, we identify a potential negative externality of political lobbying activity increased tax evasion by other firms - that has yet to draw substantial attention. In addition, we find the increase in tax evasion associated with the perceived influence of other domestic firms over policymaking is mitigated when governments are viewed as more effective or less corrupt. Our results extend the existing literature on political influence and tax evasion, summarized in Barrick and Brown (2018), by showing the effect that various sources of influence over government policymaking have on tax compliance. Overall, our findings support the conjectures in Tyler (2006) and Levi (1998) that taxpayers evade more tax when they have less confidence in 
the government's policymaking process.

Our study is subject to several limitations. Because our survey data is purely observational, we are unable to draw strong causal inferences regarding the relation between influence over policymaking and tax evasion. Furthermore, the survey data we use could suffer from endogeneity concerns. Specifically, government policies, including tax specific policies, are not necessarily randomly assigned and are likely affected by influence itself (e.g., Barrick and Brown 2018). Additionally, while we believe the study of tax evasion in developing countries is important, it is possible that our results do not generalize to more developed countries. Despite these limitations, we believe our analyses on the relation between perceived influence over government policymaking and tax evasion using archival data provides important initial evidence to the tax evasion literature. Future work, potentially using randomized controlled trials or field studies, could be very useful in identifying and confirming causal relationships.

Regardless of the methodology, we believe the relationships between tax evasion and perceived influence over policy, as well as the role of government effectiveness in these relations, is ripe for future exploration. We look forward to future work in the area. 


\section{References}

Acemoglu, D., and S. Johnson. 2005. Unbundling institutions. Journal of Political Economy 113: 949-995.

Allingham, M. G., and A. Sandmo. 1972. Income tax evasion: A theoretical analysis. Journal of Public Economics 1: 323-338.

Alm, J. 2019. What motivates tax compliance? Journal of Economic Surveys 33 (2): 353-388.

Alm, J., B. R. Jackson, and M. McKee. 1992a. Estimating the determinants of taxpayer compliance with experimental data. National Tax Journal 45 (1): 107-114.

Alm, J., G. H. McClelland, and W. D. Schulze. 1992b. Why do people pay taxes? Journal of Public Economics 48: 21-38.

Alstadsæter, A., N. Johannesen, and G. Zucman. 2017. Tax evasion and inequality. NBER Working Paper, Norwegian University of Life Sciences, University of Copenhagen, UC Berkeley.

Andreoni, J., B. Erard, and J. Feinstein. 1998. Tax compliance. Journal of Economic Literature 36: 818-860.

Ayyagari, M., A. Demirguc-Kunt, and V. Maksimovic. 2008. How well do institutional theories explain firms' perceptions of property rights? Review of Financial Studies 21: 18331871.

Ayyagari, M., A. Demirguc-Kunt, and V. Maksimovic. 2010. Formal versus informal finance: Evidence from China. Review of Financial Studies 23: 3048- 3097.

Badertscher, B. A., S. P. Katz, and S. O. Rego. 2013. The separation of ownership and control and corporate tax avoidance. Journal of Accounting and Economics 56: 228-250.

Baloria, V. P., and K. J. Klassen. 2018. Supporting tax policy change through accounting discretion: Evidence from the 2012 elections. Management Science 64 (10): 4893-4914.

Barrick, J. A., and J. L. Brown. 2018. Tax-related corporate political activity research: A literature review. Journal of the American Taxation Association forthcoming.

Barrick, J. A., and P. Frischmann. 2017. Corporate taxes and lobbying: Getting a seat at the table. Working paper, Brigham Young University and Oregon State University.

Barth, J., C. Lin, P. Lin, and F. Song. 2009. Corruption in bank lending to firms: Cross-country micro-evidence on the beneficial role of competition and information sharing. Journal of Financial Economics 91: 361-388.

Bearak, M. 2016. How global tax evasion keeps poor countries poor. Washington Post April 8. 
Beck, T., C. Lin, and Y. Ma. 2014. Why do firms evade taxes? The role of information sharing and financial sector outreach. Journal of Finance 69 (2):763-817.

Beck, T., A. Demirguc-Kunt, and V. Maksimovic. 2005. Financial and legal constraints to firm growth: Does size matter? Journal of Finance 60: 137-177.

Bertrand, M., and A. Schoar. 2003. Managing with style: The effect of managers on firm policies. Quarterly Journal of Economics 118 (4): 1169-1208.

Besley, T., and T. Persson. 2009. The origins of state capacity: Property rights, taxation, and politics. American Economic Review 99 (4): 1218-1244.

Besley, T., A. Jensen, and T. Persson. 2019. Norms, enforcement, and tax evasion. Working paper, NBER.

Blanthorne, C., and S. Kaplan. 2008. An egocentric model of the relations among the opportunity to underreport, social norms, ethical beliefs, and underreporting behavior. Accounting, Organizations and Society 33: 684-703.

Blumenthal, M., C. Christian, and J. Slemrod. 2001. Do normative appeals affect tax compliance? Evidence from a controlled experiment in Minnesota. National Tax Journal 54 (1): 125-138.

Bordignon, M. 1993. A fairness approach to income tax evasion. Journal of Public Economics 52: $345-362$.

Bott, K. M., A. W. Cappelen, E. Ø. Sørensen, and B. Tungodden. 2017. You've got mail: A randomised field experiment on tax evasion. Working paper, Norwegian School of Economics.

Barford, V., and G. Holt. 2013. Google, Amazon, and Starbucks: The rise of 'tax shaming'. $B B C$ News Magazine May 21.

Braithwaite, V. A., and M, Levi. 1998. Trust and governance. New York: Russell Sage Foundation.

Bricker, J., A. Henriques, J. Krimmel, and J. Sabelhaus. 2016. Measuring income and wealth at the top using administrative survey data. Brookings Papers on Economic Activity (Spring): 261-331.

Brink, W. D., and T. M. Porcano. 2016. The impact of culture and economic structure on tax morale and tax evasion: A country-level analysis using SEM. Advances in Taxation 23: 87-123.

Brown, J. L., K. Drake, and L. Wellman. 2015. The benefits of a relational approach to corporate political activity: Evidence from political contributions to tax policy makers. Journal of the American Taxation Association 37 (1): 69-102. 
Brown, J. R., and J. Huang. 2017. All the President's friends: Political access and firm value. Working paper, NBER.

Cabral, A. C. G., C. Kotsogiannis, and G. Myles. 2015. Self-employment and underreporting in Great Britain: Who and how much? Working paper, University of Exeter.

Casaburi, L., and U. Troiano. 2016. Ghost-house busters: The electoral response to a large antitax evasion program. Quarterly Journal of Economics 131 (1): 273-314.

Cen, W., and J. A. Doukas. 2018. CEO personal investment decisions and firm risk. European Financial Management 23 (5): 920-950.

Chen, S., X. Chen, Q. Cheng, and T. Shevlin. 2010. Are family firms more tax aggressive than non-family firms? Journal of Financial Economics 95: 41-61.

Chyz, J. A. 2013. Personally tax aggressive executives and corporate tax sheltering. Journal of Accounting and Economics 56 (2-3): 311-328.

Clotfelter, C. T. 1983. Tax evasion and tax rates: An analysis of individual returns. The Review of Economics and Statistics 65 (3): 363-373.

Coibion, O., Y. Gorodnichenko, and D. Koustas. 2017. Consumption inequality and the frequency of purchases. Working paper, NBER.

Cowell, F. A. 1990. Cheating the Government: The Economics of Evasion. Cambridge, MA: The MIT Press.

Cullen, J. B., N. Turner, and E. L. Washington. 2018. Political alignment, attitudes toward government and tax evasion. Working paper, NBER.

Davis, J. S., G. Hecht, and J. D. Perkins. 2003. Social behaviors, enforcement, and tax compliance dynamics. The Accounting Review 78 (1): 39-69.

Daunton, M. 1998. Trusting Leviathan: British Fiscal Administration from the Napoleonic Wars to the Second World War. In Trust and Governance eds., V. Braithwaite and M. Levi, 102-134. New York: Russell Sage Foundation.

DeBacker, J., B. T. Heim, A. Tran, and A. Yuskavage. 2015a. Legal enforcement and corporate behavior: An analysis of tax aggressiveness after an audit. Journal of Law and Economics 58: 291-324.

DeBacker, J., B. T. Heim, A. Tran, and A. Yuskavage. 2015b. Once bitten, twice shy? The lasting impact of IRS audits on individual tax reporting. Working paper, Indiana University.

Djankov, S., R. La Porta, F. Lopez-de-Silanes, and A. Shleifer. 2003. Courts. Quarterly Journal of Economics 118: 457-522. 
El-Erian, M. 2017. Can big institutions restore trust? Barron's October 14.

Feinstein, J. S. 1991. An econometric analysis of income tax evasion and its detection. RAND Journal of Economics 22 (1): 14-35.

Fisman, R., and S.-J. Wei. 2004. Tax rates and tax evasion: Evidence from "missing imports" in China. Journal of Political Economy 112 (2): 471-496.

Fortin, B., G. Lacroix, and M. Villeval. 2007. Tax evasion and social interactions. Journal of Public Economics 91, 2089-2112.

Frey, B. S. 1997. A constitution for knaves crowds out civic virtues. The Economic Journal 107: 1043-1053.

Frumin, A. 2015. Money has too much of an influence in politics, Americans say. MSNBC.com June 2.

Garcia, F., L. D. Opromolla, A. Vezzulli, and R. Marques. 2018. The effects of official and unofficial information on tax compliance. Working paper, CAEPR.

Geloso, V., and P. Magness. 2017. Trends and levels of income inequality in Wisconsin, 19191941: The effect of using different data sources. Working paper.

Gimpelson, V., and D. Treisman. 2018. Misperceiving inequality. Economics and Politics 30: $27-54$.

Goodwin, R. N. 2017. Democracy teeters on the income gap. The Boston Globe March 29.

Hagopian, K., and L. Ohanian. 2011. The mismeasurement of inequality. Policy Review 174: 319.

Hanlon, M., E. L. Maydew, and J. R. Thornock. 2015. Taking the long way home: U.S. tax evasion and offshore investments in U.S. equity and debt markets. The Journal of Finance 70 (1): 257-287.

Hasan, I., Hoi, C., Wui, Q., Zhang, H. 2017. Does social capital matter in corporate decisions? Evidence from corporate tax avoidance. Journal of Accounting Research (55) 3 629-668.

Helderman, R. S., S. S. Hsu, and T. Hamburger. 2016. Emails reveal how foundation donors got access to Clinton and her close aides at State Dept. The Washington Post August 22.

Henderson, B. C., and S. E. Kaplan. 2005. An examination of the role of ethics in tax compliance decisions. Journal of the American Taxation Association 27 (1): 39-72.

Hillman, A. J., G. D. Keim, and D. Schuler. 2004. Corporate political activity: A review and research agenda. Journal of Management 30 (6): 837-857.

Johnson, S., D. Kaufmann, J. McMillan, and C. Woodruff. 2000. Why do firms hide? Bribes and unofficial activity after communism. Journal of Public Economics 76: 495-520. 
Joulfaian, D. 2000. Corporate income tax evasion and managerial preferences. The Review of Economics and Statistics 82 (4): 698-701.

Kalla, J. L., and D. E. Broockman. 2016. Campaign contributions facilitate access to congressional officials: A randomized field experiment. American Journal of Political Science 60 (3): 545-558.

Kanagaretnam, K., J. Lee, C. Y. Lim, and G. Lobo. 2018. Societal trust and corporate tax avoidance. Review of Accounting Studies 23: 1588-1628.

Kaufmann, D., A. Kraay, and M. Mastruzzi. 2011. The worldwide governance indicators: Methodology and analytical issues. Hague Journal on the Rule of Law 3: 220-246.

Kim, C., and L. Zhang. 2016. Corporate political connections and tax aggressiveness. Contemporary Accounting Research 33 (1): 78-114.

Kirchler, E., E. Hoelzl, and I. Wahl. 2008. Enforced versus voluntary tax compliance: The "slippery slope" framework. Journal of Economic Psychology 29: 210-225.

Klepper, S., and D. Nagin. 1989. The anatomy of tax evasion. Journal of Law, Economics, and Organizations 5 (1): 1-24.

Kouamé, W. A. 2017. Tax morale and trust in public institutions. Working paper, University of Sherbrooke.

LaLumia, S., and J. M. Sallee. 2013. The value of honesty: Empirical estimates from the case of missing children. International Tax and Public Finance 20 (2): 192-224.

Larrimore, J., R. V. Burkhauser, G. Auten, and P. Armour. 2017. Recent trends in U.S. top income shares in tax record data using more comprehensive measures of income including accrued capital gains. Working paper, NBER.

Li, W., J. Pittman, and Z.-T. Wang. 2018. The determinants and consequences of tax audits: Some evidence from China. Journal of the American Taxation Association forthcoming.

Levi, M. 1989. Of Rule and Revenue. Berkley, CA: University of California Press.

Levi, M. 1998. A State of Trust. Trust and Governance, eds. V. Braithwaite and M. Levi. New York: Russell Sage Foundation.

McCloskey, D. N. 2014. Measured, unmeasured, mismeasured, and unjustified pessimism: A review essay of Thomas Piketty's Capital in the twenty-first century. Erasmus Journal for Philosophy and Economics 7 (2): 73-115.

Meade, J. A., and S. Li. 2015. Strategic corporate tax lobbying. Journal of the American Taxation Association 37 (2): 23-48 
Mishra, P., A. Subramanian, and P. Topalova. 2008. Tariffs, enforcement, and customs evasion: Evidence from India. Journal of Political Economy 92: 1907-1925.

Norman, J. 2016. Americans’ confidence in institutions stays low. Gallup June 13.

Piketty, T. 2015. About Capital in the twenty-first century. American Economic Review: Papers and Proceedings 105 (5): 1-6.

Piketty, T., and E. Saez. 2014. Inequality in the long run. Science 344 (6186): 838-843.

Pommerehne, W. W., A. Hart, and B. S. Frey. 1994. Tax morale, tax evasion and the choice of policy instruments in different political systems. Public Finance 49: 52-69.

Pommerehne, W. W., and H. Weck-Hannemann. 1996. Tax rates, tax administration and income tax evasion in Switzerland. Public Choice 88: 161-170.

Rapoza, K. 2004. Tax evasion is a way of life in Brazil. Washington Times July 13.

Richardson, G. 2006. Determinants of tax evasion: A cross-country investigation. Journal of International Accounting, Auditing and Taxation 15: 150-169.

Richter, B., K. Samphantharak, and J. Timmons. 2009. Lobbying and taxes. American Journal of Political Science 53 (4): 893-909.

Robbins, B. G., and E. Kiser. 2018. Legitimate authorities and rational taxpayers: An investigation of voluntary compliance and method effects in a survey experiment of income tax evasion. Working paper, New York University.

Sandmo, A. 2005. The theory of tax evasion: A retrospective view. National Tax Journal 58 (4): 643-663.

Slemrod, J. 2007. Cheating ourselves: The economics of tax evasion. Journal of Economic Perspectives 21 (1): 25-48.

Slemrod, J. 2018. Tax compliance and enforcement. Working paper, NBER.

Slemrod, J., M. Blumenthal, and C. Christian. 2001. Taxpayer response to an increased probability of audit: Evidence from a controlled experiment in Minnesota. Journal of Public Economics 79: 455-483.

Solt, F. 2016. The Standardized World Income Inequality Database. Social Science Quarterly 97 (5): 1267-1821.

Soto, A. 2012. Brazil’s secret fiscal weapon: the tax "lion.” Reuters Business News May 8.

Spicer, M. W., and S. B. Lundstedt. 1976. Understanding tax evasion. Public Finance 31 (2): 295-305. 
Stanley, L., and T. K. Hartman. 2016. What tax summaries tell us about tax, transparency, and welfare: A survey experiment in the UK. Working paper.

Stein, S. E. 2018. Auditor industry specialization and accounting estimates: Evidence from asset impairments. Auditing: A Journal of Practice and Theory forthcoming.

Svallfors, S. 2013. Government quality, egalitarianism, and attitudes to taxes and social spending: A European comparison. European Political Science Review 5 (3): 363-380.

Swanson, A. 2016. China's influence over Hollywood grows. Washington Post September 24.

The World Bank. (n.d.). About the World Bank Enterprise Surveys. Retrieved from http://microdata.worldbank.org/index.php/catalog/enterprise_surveys/about.

Torgler, B. 2003. Tax-morale, rule-governed behaviour, and trust. Constitutional Political Economy 14: 119-140.

Torgler, B. 2004. Moral suasion: An alternative tax policy strategy? Evidence from a controlled field experiment in Switzerland. Economics of Governance 5: 235-253.

Transparency International. (n.d.). Corruption Perceptions Index 2017. Retrieved from https://www.transparency.org/news/feature/corruption_perceptions_index_2017.

Tyler, T. R. 1997. Procedural fairness and compliance with the law. Swiss Journal of Economics and Statistics 133 (2): 219-240.

Tyler, T. R. 2006. Why People Obey the Law. Princeton, NJ: Princeton University Press.

Verschoor, C. C. 2018. Trust level drops dramatically in the U.S. Strategic Finance April 1.

Webley, P., H. Robben, H. Elffers, and D. Hessing. 1991. Tax Evasion: An Experimental Approach. Cambridge, UK: Cambridge University Press.

Williams, B. M. 2017. Financial accounting standards, audit profession development, and firmlevel tax evasion. Working paper. Indiana University.

Williamson, V. S. 2017. Read My Lips: Why Americans are Proud to Pay Taxes. Princeton, NJ: Princeton University Press.

Wooldridge, J. M. 2010. Econometric Analysis of Cross Section and Panel Data, Second Edition. Cambridge, MA: The MIT Press.

Zeckhauser, R. 1986. Comments: Behavioral versus rational economics: What you see is what you conquer. Journal of Business 59 (4): S435-S449. 


\section{Appendix A: Variable Definitions and Data Sources Panel A: Firm Level Data}

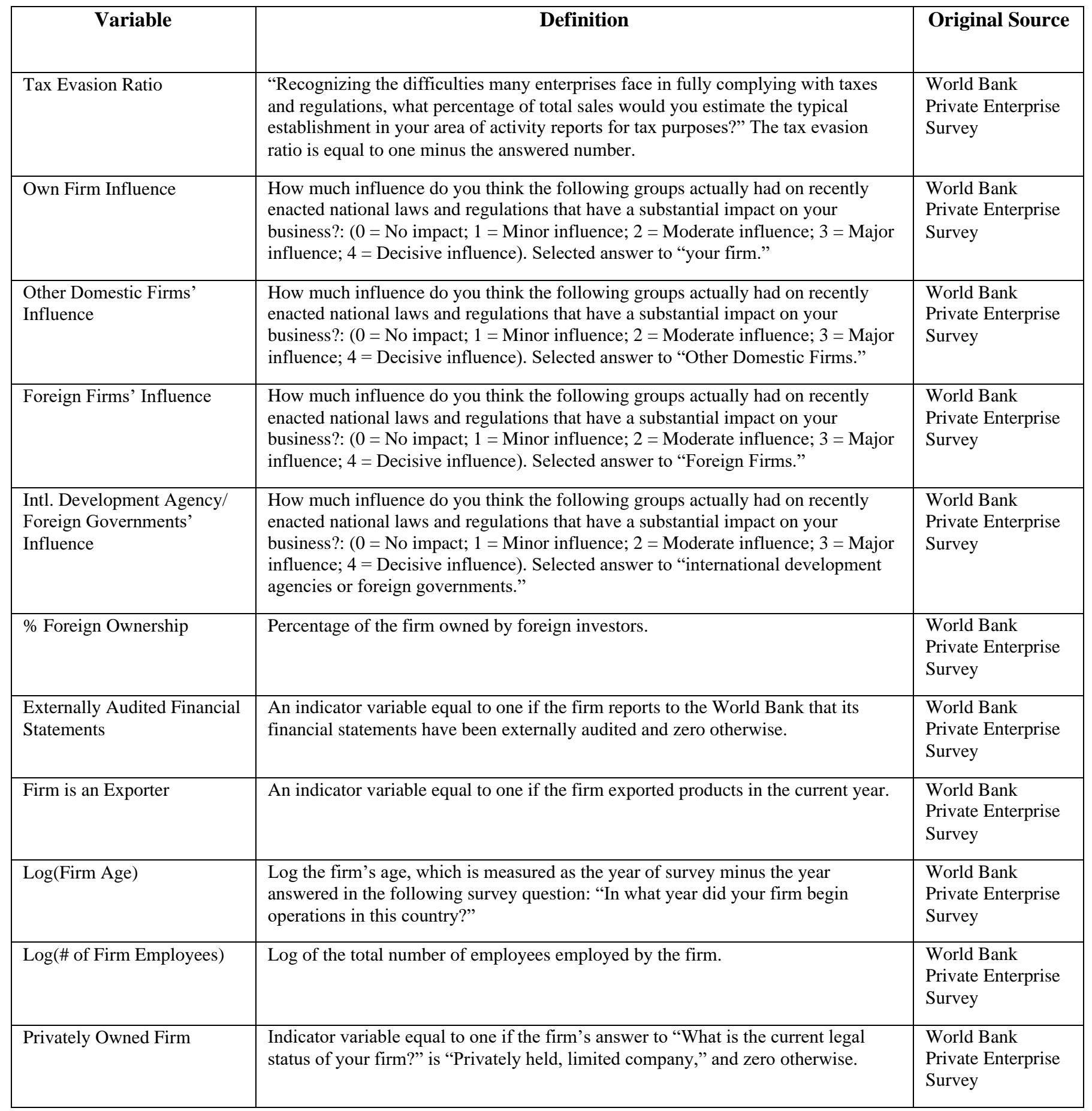




\section{Appendix A: Variable Definitions and Data Sources (Continued) Panel B: Country-Level Data}

\begin{tabular}{|c|c|c|}
\hline Variable & Definition & Original Source \\
\hline Statutory Corporate Tax Rate & $\begin{array}{l}\text { The highest marginal corporate income tax rate for each } \\
\text { country by year. We include this variable in all of our } \\
\text { regression models. }\end{array}$ & $\begin{array}{l}\text { Various data sources including } \\
\text { KPMG's tax data, Organisation for } \\
\text { Economic Co-operation and } \\
\text { Development (OECD) data, and } \\
\text { internet searches when missing. }\end{array}$ \\
\hline Log(GDP Per Capita) & Log of the gross domestic product per capita & $\begin{array}{l}\text { World Bank Development Indicators } \\
\text { (WDI) }\end{array}$ \\
\hline Control of Corruption & $\begin{array}{l}\text { Measures the extent to which public power is exercised for } \\
\text { private gain, including both petty and grand forms of } \\
\text { corruption, as well as "capture" of the state by elites and } \\
\text { private interests. Higher values indicate better control of } \\
\text { corruption. }\end{array}$ & $\begin{array}{l}\text { Kaufmann, Kraay, and Mastruzzi } \\
\text { (2011) }\end{array}$ \\
\hline Rule of Law & $\begin{array}{l}\text { Measures the extent to which agents have confidence in and } \\
\text { abide by the rules of society, and in particular the quality of } \\
\text { contract enforcement, the police, and the courts, as well as } \\
\text { the likelihood of crime and violence. Higher values mean } \\
\text { stronger law and order. Countries are assigned a score from a } \\
\text { theoretical minimum of }-2.5 \text { to a theoretical maximum of } 2.5 \text {. }\end{array}$ & $\begin{array}{l}\text { Kaufmann, Kraay, and Mastruzzi } \\
\text { (2011) }\end{array}$ \\
\hline Government Effectiveness & $\begin{array}{l}\text { Measures the quality of public services, the quality of the } \\
\text { civil service and the degree of its independence from political } \\
\text { pressures, the quality of policy formulation and } \\
\text { implementation, and the credibility of the government's } \\
\text { commitment to such policies. Countries are assigned a score } \\
\text { from a theoretical minimum of }-2.5 \text { to a theoretical maximum } \\
\text { of } 2.5 \text {. }\end{array}$ & $\begin{array}{l}\text { Kaufmann, Kraay, and Mastruzzi } \\
\text { (2011) }\end{array}$ \\
\hline $\begin{array}{l}\text { High Government } \\
\text { Effectiveness }\end{array}$ & $\begin{array}{l}\text { An indicator variable equal to } 1 \text { if the country's Government } \\
\text { Effectiveness is above the sample median and } 0 \text { otherwise. }\end{array}$ & Calculated \\
\hline $\begin{array}{l}\text { Corruption Perceptions Index } \\
\text { (CPI) }\end{array}$ & $\begin{array}{l}\text { Transparency International's Corruption Perceptions Index, } \\
\text { which is a measure of the perceived government corruption } \\
\text { by country and year according to experts and businesspeople } \\
\text { in each respective country. The CPI is a score between } 0 \text { and } \\
100 \text { with } 0 \text { being highly corrupt and } 100 \text { being a very clean } \\
\text { government. }\end{array}$ & Transparency International \\
\hline High Anti-CPI & $\begin{array}{l}\text { An indicator variable equal to } 1 \text { if the country's CPI is above } \\
\text { the sample median and } 0 \text { otherwise. High Anti-CPI thus } \\
\text { denotes relatively less government corruption. }\end{array}$ & Calculated \\
\hline
\end{tabular}


Table 1: Sample Selection

Firm-Year Obs

Number of Countries

Confidential World Bank Survey with non-missing

data on Tax Evasion and Perception of Influence over Laws

9,837

41

Missing Data for Control Variables

Final Number of Observations

7,347

37

This table provides details of our sample selection process beginning with the data from the World Bank Private Enterprise Survey and restricting the sample for non-missing data. 
Table 2: Tax Evasion and Perception of Influence over Laws

Panel A: Evasion and Influence by Country

\begin{tabular}{|c|c|c|c|c|c|c|}
\hline Country & $\mathrm{N}$ & $\begin{array}{c}\text { Tax } \\
\text { Evasion } \\
\text { Ratio } \\
\end{array}$ & $\begin{array}{l}\text { Own Firm } \\
\text { Influence }\end{array}$ & $\begin{array}{c}\text { Other } \\
\text { Domestic } \\
\text { Firms' } \\
\text { Influence }\end{array}$ & $\begin{array}{l}\text { Foreign } \\
\text { Firms' } \\
\text { Influence }\end{array}$ & $\begin{array}{c}\text { Foreign } \\
\text { Development } \\
\text { Agencies' } \\
\text { Influence }\end{array}$ \\
\hline Albania & 119 & 0.219 & 0.597 & 1.311 & 1.193 & 1.908 \\
\hline Armenia & 111 & 0.101 & 0.414 & 0.532 & 0.450 & 0.973 \\
\hline Azerbaijan & 90 & 0.141 & 0.244 & 0.444 & 0.478 & 0.211 \\
\hline Belarus & 218 & 0.081 & 0.289 & 0.775 & 0.550 & 0.959 \\
\hline Bosnia and Herzegovina & 88 & 0.320 & 0.443 & 0.784 & 0.909 & 1.773 \\
\hline Brazil & 1,368 & 0.326 & 0.813 & 1.768 & 1.961 & 1.502 \\
\hline Bulgaria & 163 & 0.185 & 0.258 & 0.626 & 0.589 & 1.031 \\
\hline Cambodia & 289 & 0.509 & 0.789 & 1.654 & 2.180 & 1.834 \\
\hline Croatia & 109 & 0.116 & 0.376 & 1.147 & 1.046 & 1.578 \\
\hline Czech Republic & 173 & 0.104 & 1.029 & 1.613 & 1.150 & 0.867 \\
\hline Ecuador & 290 & 0.199 & 0.241 & 1.169 & 1.417 & 1.259 \\
\hline Estonia & 93 & 0.077 & 0.527 & 1.398 & 0.925 & 1.161 \\
\hline Georgia & 150 & 0.352 & 0.413 & 0.753 & 0.547 & 1.053 \\
\hline Hungary & 182 & 0.113 & 0.280 & 1.066 & 1.143 & 1.203 \\
\hline Kazakhstan & 142 & 0.197 & 0.268 & 0.754 & 0.606 & 0.592 \\
\hline Kenya & 14 & 0.281 & 1.571 & 2.143 & 2.286 & 2.643 \\
\hline Kyrgyz Republic & 158 & 0.266 & 0.475 & 0.873 & 0.728 & 0.962 \\
\hline Latvia & 124 & 0.133 & 0.492 & 1.282 & 0.839 & 0.887 \\
\hline Lithuania & 130 & 0.163 & 0.438 & 1.131 & 0.769 & 0.762 \\
\hline Macedonia & 93 & 0.371 & 0.731 & 1.333 & 1.269 & 1.215 \\
\hline Mali & 129 & 0.270 & 0.194 & 0.411 & 0.729 & 0.822 \\
\hline Moldova & 197 & 0.213 & 0.426 & 1.193 & 1.168 & 1.401 \\
\hline Philippines & 233 & 0.209 & 0.614 & 1.167 & 1.588 & 1.386 \\
\hline Poland & 451 & 0.099 & 0.293 & 1.149 & 1.499 & 2.091 \\
\hline Romania & 193 & 0.131 & 0.446 & 1.041 & 1.145 & 1.378 \\
\hline Russian Federation & 305 & 0.166 & 0.259 & 0.767 & 0.554 & 0.551 \\
\hline Senegal & 169 & 0.793 & 0.095 & 0.586 & 1.089 & 1.047 \\
\hline Slovakia & 95 & 0.154 & 0.695 & 1.474 & 1.505 & 1.579 \\
\hline Slovenia & 129 & 0.188 & 0.543 & 1.186 & 0.690 & 1.070 \\
\hline Sri Lanka & 96 & 0.073 & 0.563 & 1.146 & 1.406 & 1.271 \\
\hline Tajikistan & 148 & 0.329 & 0.764 & 1.324 & 0.716 & 0.851 \\
\hline Tanzania & 27 & 0.328 & 1.889 & 1.963 & 2.407 & 2.852 \\
\hline Turkey & 399 & 0.151 & 0.201 & 0.689 & 1.328 & 1.995 \\
\hline Uganda & 60 & 0.189 & 1.267 & 1.567 & 2.633 & 3.083 \\
\hline Ukraine & 326 & 0.125 & 0.334 & 1.113 & 1.006 & 1.672 \\
\hline Uzbekistan & 240 & 0.078 & 0.313 & 0.742 & 0.588 & 0.600 \\
\hline Zambia & 46 & 0.177 & 1.500 & 1.870 & 1.848 & 3.152 \\
\hline Total & 7,347 & 0.225 & 0.507 & 1.175 & 1.255 & 1.351 \\
\hline
\end{tabular}


Table 2: Tax Evasion and Perception of Influence over Laws (Continued) Panel B: Evasion and Influence by Industry

\begin{tabular}{|c|c|c|c|c|c|c|}
\hline Industry & $\mathrm{N}^{\mathrm{T}}$ & $\begin{array}{c}\text { Tax Evasion } \\
\text { Ratio } \\
\end{array}$ & $\begin{array}{l}\text { Your Firm's } \\
\text { Influence }\end{array}$ & $\begin{array}{l}\text { Other Domestic } \\
\text { Firms' Influence }\end{array}$ & $\begin{array}{c}\text { Foreign Firms' } \\
\text { Influence }\end{array}$ & $\begin{array}{c}\text { Foreign Development } \\
\text { Agencies' Influence }\end{array}$ \\
\hline Textiles & 245 & 0.245 & 0.596 & 1.327 & 1.620 & 1.437 \\
\hline Leather & 184 & 0.319 & 0.543 & 1.641 & 1.804 & 1.451 \\
\hline Garments & 764 & 0.296 & 0.620 & 1.338 & 1.609 & 1.458 \\
\hline Agriculture & 202 & 0.488 & 0.658 & 1.119 & 1.619 & 1.851 \\
\hline Food & 446 & 0.191 & 0.529 & 1.229 & 1.318 & 1.274 \\
\hline Beverages & 240 & 0.168 & 0.500 & 1.004 & 0.896 & 1.213 \\
\hline Metals and machinery & 563 & 0.205 & 0.515 & 1.172 & 1.293 & 1.393 \\
\hline Electronics & 106 & 0.232 & 0.972 & 1.491 & 1.962 & 1.642 \\
\hline Chemicals & 232 & 0.249 & 0.539 & 1.216 & 1.547 & 1.392 \\
\hline Construction & 612 & 0.178 & 0.405 & 1.018 & 1.002 & 1.257 \\
\hline Wood and furniture & 458 & 0.337 & 0.541 & 1.452 & 1.557 & 1.480 \\
\hline Non-metallics and plastics & 139 & 0.200 & 0.432 & 1.036 & 1.180 & 1.194 \\
\hline Paper & 87 & 0.141 & 0.621 & 1.092 & 0.920 & 1.299 \\
\hline IT services & 71 & 0.296 & 0.437 & 1.394 & 1.761 & 1.662 \\
\hline Other manufacturing & 40 & 0.151 & 0.650 & 1.075 & 0.925 & 1.625 \\
\hline Telecommunication & 52 & 0.074 & 1.173 & 1.404 & 0.942 & 1.442 \\
\hline Advertising & 226 & 0.158 & 0.558 & 1.124 & 0.748 & 1.381 \\
\hline Other services & 344 & 0.223 & 0.587 & 1.145 & 1.029 & 1.012 \\
\hline Retail and wholesale & 1,346 & 0.189 & 0.303 & 1.011 & 1.119 & 1.352 \\
\hline Hotels and restaurants & 316 & 0.241 & 0.364 & 0.956 & 0.918 & 1.114 \\
\hline Transport & 337 & 0.163 & 0.665 & 1.160 & 0.953 & 1.288 \\
\hline Real estate & 162 & 0.154 & 0.370 & 1.037 & 0.796 & 1.074 \\
\hline Mining & 53 & 0.094 & 0.698 & 0.925 & 0.642 & 1.000 \\
\hline Auto & 122 & 0.226 & 0.787 & 1.730 & 2.098 & 1.656 \\
\hline Total & 7,347 & 0.225 & 0.507 & 1.175 & 1.255 & 1.351 \\
\hline
\end{tabular}

This table presents averages for our variables of interest by country in Panel A and by industry in Panel B. The variables include Tax Evasion Ratio which is equal to 1 minus the percent of sales reported as answered on the World Bank Private Enterprise Survey. Own Firm Influence is a firm's perceived level of its own influence over government policy. Similarly, Other Domestic Firms' Influence, Foreign Firms' Influence, and Foreign Development Agencies' Influence measure the perceived influence over government policy of other domestic firms, foreign firms, and foreign development agencies/governments, respectively. Industry classification is determined by the World Bank. 
Table 3: Descriptive Statistics

\begin{tabular}{lrrrrr}
\hline \hline Variable & N & Mean & $\begin{array}{r}\text { Std. } \\
\text { Dev. }\end{array}$ & Min & Max \\
\hline Tax Evasion Ratio & 7,347 & 0.225 & 0.278 & 0.000 & 1.000 \\
Own Firm Influence & 7,347 & 0.507 & 0.922 & 0.000 & 4.000 \\
Other Domestic Firms' Influence & 7,347 & 1.175 & 1.108 & 0.000 & 4.000 \\
Foreign Firms' Influence & 7,347 & 1.255 & 1.309 & 0.000 & 4.000 \\
Intl. Development Agency/ Foreign & & & & & \\
Governments' Influence & 7,347 & 1.351 & 1.374 & 0.000 & 4.000 \\
\% Foreign Ownership & 7,347 & 0.115 & 0.293 & 0.000 & 1.000 \\
Statutory Corporate Tax Rate & 7,347 & 0.265 & 0.081 & 0.075 & 0.514 \\
Externally Audited Financial Statements & 7,347 & 0.464 & 0.499 & 0.000 & 1.000 \\
Firm is an Exporter & 7,347 & 0.200 & 0.400 & 0.000 & 1.000 \\
Log(Firm Age) & 7,347 & 2.450 & 0.790 & 0.000 & 5.313 \\
Log(\# of Firm Employees) & 7,347 & 3.507 & 1.566 & 0.693 & 9.206 \\
Privately Owned Firm & 7,347 & 0.386 & 0.487 & 0.000 & 1.000 \\
Control of Corruption & 7,347 & -0.386 & 0.538 & -1.140 & 0.720 \\
Rule of Law & 7,347 & -0.380 & 0.620 & -1.410 & 0.960 \\
Government Effectiveness & 7,347 & -0.176 & 0.602 & -1.260 & 1.020 \\
Log(GDP Per Capita) & 7,347 & 7.479 & 0.986 & 5.256 & 9.359 \\
\hline
\end{tabular}

This table presents descriptive statistics for our variables of interest and control variables used throughout our analyses. The variables include Tax Evasion Ratio which is equal to 1 minus the percent of sales reported as answered on the World Bank Private Enterprise Survey. Own Firm Influence is a firm's perceived level of its own influence over government policy. Similarly, Other Domestic Firms' Influence, Foreign Firms' Influence, and Foreign Development Agencies' Influence measure the perceived influence over government policy of other domestic firms, foreign firms, and foreign development agencies/governments, respectively. Control variables are as described in Appendix A. 
Table 4:

Univariate Correlation Matrix

\begin{tabular}{|c|c|c|c|c|c|c|c|c|c|c|c|c|c|c|c|c|c|}
\hline & & 1 & 2 & 3 & 4 & 5 & 6 & 7 & 8 & 9 & 10 & 11 & 12 & 13 & 14 & 15 & \\
\hline 1 & Tax Evasion Ratio & 1.000 & & & & & & & & & & & & & & & \\
\hline 2 & Own Firm Influence & 0.020 & 1.000 & & & & & & & & & & & & & & \\
\hline 3 & $\begin{array}{l}\text { Other Domestic Firms' } \\
\text { Influence }\end{array}$ & $\mathbf{0 . 0 7 7}$ & 0.381 & 1.000 & & & & & & & & & & & & & \\
\hline 4 & Foreign Firms' Influence & 0.105 & $\mathbf{0 . 1 3 7}$ & 0.474 & 1.000 & & & & & & & & & & & & \\
\hline 5 & $\begin{array}{l}\text { Intl. Development } \\
\text { Agency/Foreign } \\
\text { Governments' Influence }\end{array}$ & 0.029 & -0.007 & 0.205 & 0.503 & 1.000 & & & & & & & & & & & \\
\hline 7 & Statutory Corporate Tax Rate & 0.072 & 0.070 & 0.113 & 0.185 & 0.102 & -0.032 & 1.000 & & & & & & & & & \\
\hline 8 & $\begin{array}{l}\text { Externally Audited Financial } \\
\text { Statements }\end{array}$ & -0.168 & 0.039 & $-\mathbf{0 . 0 3 1}$ & -0.043 & 0.019 & 0.222 & -0.087 & 1.000 & & & & & & & & \\
\hline 9 & Firm is an Exporter & -0.056 & 0.054 & 0.003 & 0.040 & 0.064 & 0.251 & $\mathbf{0 . 0 2 3}$ & 0.209 & 1.000 & & & & & & & \\
\hline 10 & Log(Firm Age) & -0.087 & 0.103 & 0.034 & 0.014 & 0.003 & -0.080 & 0.144 & 0.134 & 0.126 & 1.000 & & & & & & \\
\hline 11 & Log(\# of Firm Employees) & -0.139 & 0.180 & 0.067 & 0.047 & $\mathbf{0 . 0 2 7}$ & $\mathbf{0 . 1 7 2}$ & 0.106 & 0.309 & 0.334 & 0.373 & 1.000 & & & & & \\
\hline 12 & Privately Owned Firm & 0.034 & 0.083 & 0.166 & 0.169 & 0.054 & 0.080 & 0.334 & -0.059 & 0.070 & 0.060 & 0.166 & 1.000 & & & & \\
\hline 13 & Control of Corruption & -0.012 & 0.068 & 0.157 & 0.140 & 0.062 & -0.017 & 0.279 & -0.054 & 0.039 & 0.152 & 0.043 & 0.224 & 1.000 & & & \\
\hline 14 & Rule of Law & -0.117 & -0.003 & 0.034 & 0.042 & 0.073 & 0.028 & 0.253 & 0.083 & 0.068 & 0.114 & -0.032 & 0.000 & 0.821 & 1.000 & & \\
\hline 16 & Log(GDP Per Capita) & -0.159 & -0.015 & 0.079 & 0.057 & 0.039 & -0.027 & 0.182 & -0.018 & 0.027 & 0.139 & 0.017 & 0.123 & 0.748 & 0.702 & 0.820 & 1.000 \\
\hline
\end{tabular}

This table presents the Pearson correlation matrix for our variables of interest and control variables used throughout our analyses. Tax Evasion Ratio, which is equal to 1 minus the percent of sales reported as answered on the World Bank Private Enterprise Survey. Own Firm Influence is a firm's perceived level of its own influence over government policy. Similarly, Other Domestic Firms' Influence, Foreign Firms' Influence, and Foreign Development Agencies' Influence measure the perceived influence over government policy of other domestic firms, foreign firms, and foreign development agencies/governments, respectively. Bolded coefficients are significant that the $10 \%$ level. Additional details related to specific variables and the corresponding survey questions are presented in Appendix A 
Table 5: Regression Analysis

Panel A: Without Country-Level Control Variables

\begin{tabular}{|c|c|c|c|c|c|}
\hline \multirow[b]{2}{*}{ VARIABLES } & \multicolumn{4}{|c|}{ DV = Tax Evasion Ratio } & \multirow[b]{2}{*}{5} \\
\hline & 1 & 2 & 3 & 4 & \\
\hline Own Firm Influence on Laws & $\begin{array}{l}0.005 \\
(0.60)\end{array}$ & & & & $\begin{array}{l}-0.002 \\
(-0.28)\end{array}$ \\
\hline Other Domestic Firm's Influence on Laws & & $\begin{array}{c}0.022 * * * \\
(2.62)\end{array}$ & & & $\begin{array}{c}0.019 * * \\
(2.06)\end{array}$ \\
\hline Foreign Firm's Influence on Laws & & & $\begin{array}{c}0.014 * * * \\
(3.33)\end{array}$ & & $\begin{array}{l}0.004 \\
(0.79)\end{array}$ \\
\hline $\begin{array}{l}\text { Intl. Development Agency/Foreign } \\
\text { Government's Influence on Laws }\end{array}$ & & & & $\begin{array}{c}0.011 * * \\
(2.28)\end{array}$ & $\begin{array}{l}0.007 \\
(1.11)\end{array}$ \\
\hline$\%$ Foreign Ownership & $\begin{array}{c}-0.071 * * * \\
(-4.18)\end{array}$ & $\begin{array}{c}-0.071 \text { *** } \\
(-4.18)\end{array}$ & $\begin{array}{c}-0.070 * * * \\
(-4.11)\end{array}$ & $\begin{array}{c}-0.071 * * * \\
(-4.18)\end{array}$ & $\begin{array}{c}-0.071 * * * \\
(-4.16)\end{array}$ \\
\hline Statutory Corporate Tax Rate & $\begin{array}{l}-0.677 \\
(-0.87)\end{array}$ & $\begin{array}{l}-0.746 \\
(-0.96)\end{array}$ & $\begin{array}{l}-0.737 \\
(-0.95)\end{array}$ & $\begin{array}{l}-0.607 \\
(-0.81)\end{array}$ & $\begin{array}{l}-0.713 \\
(-0.95)\end{array}$ \\
\hline Externally Audited Financial Statements & $\begin{array}{c}-0.044 * * * \\
(-3.38)\end{array}$ & $\begin{array}{c}-0.046^{* * *} \\
(-3.67)\end{array}$ & $\begin{array}{c}-0.045 * * * \\
(-3.46)\end{array}$ & $\begin{array}{c}-0.044 * * * \\
(-3.30)\end{array}$ & $\begin{array}{c}-0.046 * * * \\
(-3.76)\end{array}$ \\
\hline Firm is an Exporter & $\begin{array}{l}0.002 \\
(0.10)\end{array}$ & $\begin{array}{l}0.002 \\
(0.11)\end{array}$ & $\begin{array}{l}-0.000 \\
(-0.01)\end{array}$ & $\begin{array}{l}-0.000 \\
(-0.01)\end{array}$ & $\begin{array}{l}0.000 \\
(0.01)\end{array}$ \\
\hline Log(Firm Age) & $\begin{array}{c}-0.029 * * * \\
(-2.96)\end{array}$ & $\begin{array}{c}-0.029 * * * \\
(-2.96)\end{array}$ & $\begin{array}{c}-0.028^{* * *} * \\
(-2.92)\end{array}$ & $\begin{array}{c}-0.028^{* * *} \\
(-2.94)\end{array}$ & $\begin{array}{c}-0.028 * * * \\
(-2.90)\end{array}$ \\
\hline Log(\# of Firm Employees) & $\begin{array}{c}-0.042^{* * *} \\
(-8.10)\end{array}$ & $\begin{array}{c}-0.042^{* * *} \\
(-8.45)\end{array}$ & $\begin{array}{c}-0.042^{* * *} \\
(-8.45)\end{array}$ & $\begin{array}{c}-0.042^{* * *} \\
(-8.51)\end{array}$ & $\begin{array}{c}-0.042 * * * \\
(-8.25)\end{array}$ \\
\hline Privately Owned Firm & $\begin{array}{l}0.006 \\
(0.41)\end{array}$ & $\begin{array}{l}0.004 \\
(0.30)\end{array}$ & $\begin{array}{l}0.005 \\
(0.33)\end{array}$ & $\begin{array}{l}0.005 \\
(0.38)\end{array}$ & $\begin{array}{l}0.004 \\
(0.28)\end{array}$ \\
\hline Constant & $\begin{array}{c}0.476^{* * *} * \\
(4.02) \\
\end{array}$ & $\begin{array}{c}0.460 * * * \\
(4.03) \\
\end{array}$ & $\begin{array}{c}0.465^{* * * *} \\
(4.03) \\
\end{array}$ & $\begin{array}{c}0.444 * * * \\
(4.08) \\
\end{array}$ & $\begin{array}{c}0.440^{* * *} \\
(4.19)\end{array}$ \\
\hline Observations & 7,347 & 7,347 & 7,347 & 7,347 & 7,347 \\
\hline Pseudo R-squared & 0.226 & 0.228 & 0.227 & 0.227 & 0.229 \\
\hline Country and Industry Fixed Effects? & Yes & Yes & Yes & Yes & Yes \\
\hline
\end{tabular}


Table 5: Regression Analysis (Continued)

Panel B: With Country-Level Control Variables

\begin{tabular}{|c|c|c|c|c|c|}
\hline \multirow[b]{2}{*}{ VARIABLES } & \multicolumn{5}{|c|}{ DV = Tax Evasion Ratio } \\
\hline & 1 & 2 & 3 & 4 & 5 \\
\hline \multirow[t]{2}{*}{ Own Firm Influence } & 0.005 & & & & -0.002 \\
\hline & $(0.57)$ & & & & $(-0.27)$ \\
\hline \multirow[t]{2}{*}{ Other Domestic Firms' Influence } & & $0.021^{* *}$ & & & $0.018^{* *}$ \\
\hline & & $(2.54)$ & & & $(1.97)$ \\
\hline \multirow[t]{2}{*}{ Foreign Firms' Influence } & & & $0.014 * * *$ & & 0.004 \\
\hline & & & $(3.35)$ & & $(0.77)$ \\
\hline \multirow[t]{2}{*}{$\begin{array}{l}\text { Intl. Development Agency/Foreign } \\
\text { Governments' Influence }\end{array}$} & & & & $0.011^{* *}$ & 0.006 \\
\hline & & & & $(2.23)$ & (1.04) \\
\hline \multirow[t]{2}{*}{$\%$ Foreign Ownership } & $-0.072 * * *$ & $-0.072 * * *$ & $-0.071 * * *$ & $-0.072 * * *$ & $-0.072 * * *$ \\
\hline & $(-4.24)$ & $(-4.25)$ & $(-4.17)$ & $(-4.24)$ & $(-4.22)$ \\
\hline \multirow[t]{2}{*}{ Statutory Corporate Tax Rate } & $44.592 * * *$ & $44.201 * * *$ & $44.292 * * *$ & $44.522 * * *$ & $44.127 * * *$ \\
\hline & (27.78) & $(29.17)$ & $(28.10)$ & $(28.24)$ & (28.78) \\
\hline \multirow[t]{2}{*}{ Externally Audited Financial Statements } & $-0.048 * * *$ & $-0.050 * * *$ & $-0.049 * * *$ & $-0.048 * * *$ & $-0.050 * * *$ \\
\hline & $(-4.09)$ & $(-4.39)$ & $(-4.16)$ & $(-4.01)$ & $(-4.49)$ \\
\hline \multirow[t]{2}{*}{ Firm is an Exporter } & -0.001 & -0.000 & -0.002 & -0.002 & -0.002 \\
\hline & $(-0.03)$ & $(-0.01)$ & $(-0.14)$ & $(-0.14)$ & $(-0.11)$ \\
\hline \multirow[t]{2}{*}{ Log(Firm Age) } & $-0.029 * * *$ & $-0.028 * * *$ & $-0.028 * * *$ & $-0.028 * * *$ & $-0.028 * * *$ \\
\hline & $(-2.88)$ & $(-2.88)$ & $(-2.85)$ & $(-2.86)$ & $(-2.82)$ \\
\hline \multirow[t]{2}{*}{$\log (\#$ of Firm Employees) } & $-0.043 * * *$ & $-0.042 * * *$ & $-0.042 * * *$ & $-0.042 * * *$ & $-0.042 * * *$ \\
\hline & $(-7.68)$ & $(-7.98)$ & $(-7.95)$ & $(-8.00)$ & $(-7.79)$ \\
\hline \multirow[t]{2}{*}{ Privately Owned Firm } & 0.010 & 0.008 & 0.008 & 0.009 & 0.008 \\
\hline & $(0.66)$ & $(0.55)$ & $(0.59)$ & $(0.64)$ & $(0.54)$ \\
\hline \multirow[t]{2}{*}{ Control of Corruption } & $10.511 * * *$ & $10.446^{* * *}$ & $10.495 * * *$ & $10.622 * * *$ & $10.515^{* * *}$ \\
\hline & $(23.50)$ & $(24.51)$ & $(23.49)$ & $(23.03)$ & $(23.20)$ \\
\hline \multirow[t]{2}{*}{ Rule of Law } & $0.324 * * *$ & $0.368^{* * *}$ & $0.338 * * *$ & $0.340^{* * *}$ & $0.380 * * *$ \\
\hline & $(5.54)$ & $(6.29)$ & $(5.82)$ & $(5.69)$ & $(6.09)$ \\
\hline \multirow[t]{2}{*}{ Government Effectiveness } & $-7.418 * * *$ & $-7.310 * * *$ & $-7.343 * * *$ & $-7.310 * * *$ & $-7.237 * * *$ \\
\hline & $(-27.69)$ & $(-27.83)$ & $(-27.35)$ & $(-26.98)$ & $(-26.91)$ \\
\hline \multirow[t]{2}{*}{ Log(GDP Per Capita) } & $3.249 * * *$ & $3.245^{* * *}$ & $3.218 * * *$ & $3.174 * * *$ & $3.194 * * *$ \\
\hline & $(24.32)$ & $(25.47)$ & $(25.78)$ & $(26.02)$ & $(25.68)$ \\
\hline \multirow[t]{2}{*}{ Constant } & $-24.854 * * *$ & $-24.750 * * *$ & $-24.562 * * *$ & $-24.145^{* * *}$ & $-24.272 * * *$ \\
\hline & $(-27.25)$ & $(-28.91)$ & $(-28.77)$ & $(-27.95)$ & $(-28.19)$ \\
\hline Observations & 7,347 & 7,347 & 7,347 & 7,347 & 7,347 \\
\hline Pseudo R-squared & 0.231 & 0.233 & 0.232 & 0.232 & 0.234 \\
\hline Country and Industry Fixed Effects? & Yes & Yes & Yes & Yes & Yes \\
\hline \multicolumn{6}{|c|}{$\begin{array}{l}\text { This table presents the multivariate regression estimates of tax evasion on various groups influencing government policy with and without control } \\
\text { variables. Panel A presents results excluding country-level controls whereas Panel B includes country-level control variables (see Appendix A). } \\
\text { The dependent variable in each model is Tax Evasion Ratio which is equal to } 1 \text { minus the percent of sales reported as answered on the World } \\
\text { Bank Private Enterprise Survey. Own Firm Influence is a firm's perceived level of its own influence over government policy. Similarly, Other } \\
\text { Domestic Firms' Influence, Foreign Firms' Influence, and Foreign Development Agencies' Influence measure the perceived influence over } \\
\text { government policy of other domestic firms, foreign firms, and foreign development agencies/governments, respectively. Additional details related } \\
\text { to specific variable measures and the corresponding survey questions are presented in Appendix A. Control variables are as defined in Appendix } \\
\text { A. Robust t-statistics calculated using standard errors clustered by country are presented in parentheses with } * * * \text { signifying a p<0.01, ** } \\
\text { representing a p }<0.05 \text {, and * representing a p }<0.10 \text {. }\end{array}$} \\
\hline
\end{tabular}


Table 6: Government Effectiveness Interactions

\begin{tabular}{|c|c|c|c|c|c|}
\hline \multirow[b]{2}{*}{ VARIABLES } & \multicolumn{5}{|c|}{ DV = Tax Evasion Ratio } \\
\hline & 1 & 2 & 3 & 4 & 5 \\
\hline \multirow[t]{2}{*}{ High Gov. Effectiveness * Own Firm Influence } & -0.018 & & & & -0.010 \\
\hline & $(-1.27)$ & & & & $(-0.81)$ \\
\hline \multirow[t]{2}{*}{ High Gov. Effectiveness * Other Domestic Firm Influence } & & -0.013 & & & -0.016 \\
\hline & & $(-0.97)$ & & & $(-1.07)$ \\
\hline \multirow[t]{2}{*}{ High Gov. Effectiveness * Foreign Firm Influence } & & & 0.002 & & 0.014 \\
\hline & & & $(0.23)$ & & $(1.33)$ \\
\hline \multirow{3}{*}{$\begin{array}{l}\text { High Gov. Effectiveness * Intl. Development Agency/Foreig, } \\
\text { Government's Influence }\end{array}$} & & & & & \\
\hline & & & & -0.006 & -0.012 \\
\hline & & & & $(-0.63)$ & $(-1.10)$ \\
\hline \multirow[t]{2}{*}{ Own Firm Influence } & 0.016 & & & & 0.004 \\
\hline & $(1.55)$ & & & & $(0.40)$ \\
\hline \multirow[t]{2}{*}{ Other Domestic Firm's Influence } & & $0.029 * * *$ & & & $0.027 * * *$ \\
\hline & & $(4.23)$ & & & $(3.48)$ \\
\hline \multirow[t]{2}{*}{ Foreign Firm's Influence } & & & $0.013^{*}$ & & -0.003 \\
\hline & & & $(1.66)$ & & $(-0.33)$ \\
\hline \multirow[t]{2}{*}{ Intl. Development Agency/Foreign Government's Influence } & & & & $0.015^{*}$ & 0.013 \\
\hline & & & & $(1.78)$ & $(1.49)$ \\
\hline \multirow[t]{2}{*}{$\%$ Foreign Ownership } & $-0.071 * * *$ & $-0.071 * * *$ & $-0.070^{* * *}$ & $-0.071^{* * *}$ & $-0.071 * * *$ \\
\hline & $(-4.17)$ & $(-4.18)$ & $(-4.12)$ & $(-4.17)$ & $(-4.17)$ \\
\hline \multirow[t]{2}{*}{ Statutory Corporate Tax Rate } & -0.676 & -0.773 & -0.731 & -0.585 & -0.669 \\
\hline & $(-0.87)$ & $(-1.01)$ & $(-0.93)$ & $(-0.78)$ & $(-0.88)$ \\
\hline \multirow[t]{2}{*}{ Externally Audited Financial Statements } & $-0.044 * * *$ & $-0.046^{* * *}$ & $-0.045^{* * *}$ & $-0.043^{* * *}$ & $-0.046 * * *$ \\
\hline & $(-3.40)$ & $(-3.68)$ & $(-3.46)$ & $(-3.30)$ & $(-3.77)$ \\
\hline \multirow[t]{2}{*}{ Firm is an Exporter } & 0.001 & 0.002 & -0.000 & -0.000 & -0.000 \\
\hline & $(0.06)$ & $(0.12)$ & $(-0.01)$ & $(-0.01)$ & $(-0.00)$ \\
\hline \multirow[t]{2}{*}{ Log(Firm Age) } & $-0.029 * * *$ & $-0.029 * * *$ & $-0.028 * * *$ & $-0.028 * * *$ & $-0.028 * * *$ \\
\hline & $(-2.99)$ & $(-2.92)$ & $(-2.93)$ & $(-2.93)$ & $(-2.88)$ \\
\hline \multirow[t]{2}{*}{ Log(\# of Firm Employees) } & $-0.042 * * *$ & $-0.042 * * *$ & $-0.042 * * *$ & $-0.042 * * *$ & $-0.042 * * *$ \\
\hline & $(-8.19)$ & $(-8.50)$ & $(-8.47)$ & $(-8.48)$ & $(-8.35)$ \\
\hline \multirow[t]{2}{*}{ Privately Owned Firm } & 0.006 & 0.004 & 0.005 & 0.005 & 0.004 \\
\hline & $(0.43)$ & $(0.30)$ & $(0.33)$ & $(0.37)$ & $(0.29)$ \\
\hline \multirow[t]{2}{*}{ High Government Effectiveness } & 0.022 & 0.057 & 0.017 & 0.006 & 0.046 \\
\hline & $(0.16)$ & $(0.42)$ & $(0.12)$ & $(0.05)$ & $(0.34)$ \\
\hline \multirow[t]{2}{*}{ Constant } & $0.365^{* * *}$ & $0.365^{* * *} *$ & $0.365^{* * *}$ & $0.365^{* * *}$ & $0.364 * * *$ \\
\hline & $(13.24)$ & $(13.35)$ & $(13.24)$ & $(13.24)$ & $(13.30)$ \\
\hline Observations & 7,347 & 7,347 & 7,347 & 7,347 & 7,347 \\
\hline Pseudo R-Squared & 0.226 & 0.228 & 0.227 & 0.227 & 0.229 \\
\hline Country and Industry FE? & Yes & Yes & Yes & Yes & Yes \\
\hline \multicolumn{6}{|c|}{$\begin{array}{l}\text { This table presents the multivariate regression estimates of tax evasion on various groups influencing government policy with control variables. } \\
\text { The dependent variable in each model is Tax Evasion Ratio which is equal to } 1 \text { minus the percent of sales reported as answered on the World } \\
\text { Bank Private Enterprise Survey. Own Firm Influence is a firm's perceived level of its own influence over government policy. Similarly, Other } \\
\text { Domestic Firms' Influence, Foreign Firms' Influence, and Foreign Development Agencies' Influence measure the perceived influence over } \\
\text { government policy of other domestic firms, foreign firms, and foreign development agencies/governments, respectively. High Government } \\
\text { Effectiveness measures perceptions of the quality of the government and takes the value of } 1 \text { if the value of government effectiveness is above the } \\
\text { sample median and } 0 \text { otherwise. Additional details related to specific variable measures and the corresponding survey questions are presented in } \\
\text { Appendix A. Control variables are as defined in Appendix A. Robust t-statistics calculated using standard errors clustered by country are } \\
\text { presented in parentheses with } * * * \text { signifying a } p<0.01 \text {, ** representing a p }<0.05 \text {, and } * \text { representing a p }<0.10 \text {. }\end{array}$} \\
\hline
\end{tabular}


Table 7: Anti-Corruption Perceptions Index Interactions

\begin{tabular}{|c|c|c|c|c|c|}
\hline \multirow[b]{2}{*}{ VARIABLES } & \multicolumn{5}{|c|}{ DV = Tax Evasion Ratio } \\
\hline & 1 & 2 & 3 & 4 & 5 \\
\hline \multirow[t]{2}{*}{ High Anti-CPI * Own Firm Influence } & -0.016 & & & & -0.011 \\
\hline & $(-1.17)$ & & & & $(-0.92)$ \\
\hline \multirow[t]{2}{*}{ High Anti-CPI * Other Domestic Firm's Influence } & & -0.008 & & & -0.010 \\
\hline & & $(-0.63)$ & & & $(-0.67)$ \\
\hline \multirow[t]{2}{*}{ High Anti-CPI * Foreign Firm's Influence } & & & 0.004 & & 0.013 \\
\hline & & & $(0.47)$ & & $(1.27)$ \\
\hline \multirow[t]{2}{*}{ High Anti-CPI * Intl. Development Agency/Foreign Government's Influence } & & & & -0.004 & -0.010 \\
\hline & & & & $(-0.47)$ & $(-0.94)$ \\
\hline \multirow[t]{2}{*}{ Own Firm Influence } & $0.020^{*}$ & & & & 0.009 \\
\hline & $(1.86)$ & & & & $(0.93)$ \\
\hline \multirow[t]{2}{*}{ Other Domestic Firm's Influence } & & $0.024 * * *$ & & & $0.017 * *$ \\
\hline & & $(3.71)$ & & & $(2.56)$ \\
\hline \multirow[t]{2}{*}{ Foreign Firm's Influence } & & & $0.016^{* *}$ & & 0.009 \\
\hline & & & $(2.26)$ & & $(1.08)$ \\
\hline \multirow[t]{2}{*}{ Intl. Development Agency/Foreign Government's Influence } & & & & 0.007 & 0.001 \\
\hline & & & & $(1.02)$ & $(0.18)$ \\
\hline \multirow[t]{2}{*}{$\%$ Foreign Ownership } & $-0.051 * * *$ & $-0.052 * * *$ & $-0.051^{* * *}$ & $-0.052 * * *$ & $-0.052 * * *$ \\
\hline & $(-2.82)$ & $(-2.89)$ & $(-2.80)$ & $(-2.89)$ & $(-2.81)$ \\
\hline \multirow[t]{2}{*}{ Statutory Corporate Tax Rate } & -0.894 & -0.998 & -0.959 & -0.834 & -0.999 \\
\hline & $(-1.01)$ & $(-1.15)$ & $(-1.08)$ & $(-0.97)$ & $(-1.18)$ \\
\hline \multirow[t]{2}{*}{ Externally Audited Financial Statements } & $-0.047 * * *$ & $-0.047 * * *$ & $-0.047 * * *$ & $-0.046^{* * *}$ & $-0.048^{* * *}$ \\
\hline & $(-3.52)$ & $(-3.64)$ & $(-3.59)$ & $(-3.38)$ & $(-3.82)$ \\
\hline \multirow[t]{2}{*}{ Firm is an Exporter } & 0.009 & 0.010 & 0.008 & 0.008 & 0.008 \\
\hline & $(0.47)$ & $(0.52)$ & $(0.44)$ & $(0.45)$ & $(0.41)$ \\
\hline \multirow[t]{2}{*}{ Log(Firm Age $)$} & $-0.025^{* * *}$ & $-0.024 * * *$ & $-0.023 * * *$ & $-0.024 * * *$ & $-0.024 * * *$ \\
\hline & $(-2.89)$ & $(-2.85)$ & $(-2.81)$ & $(-2.82)$ & $(-2.79)$ \\
\hline \multirow[t]{2}{*}{ Log(\# of Firm Employees) } & $-0.043^{* * *}$ & $-0.043^{* * *}$ & $-0.043^{* * *}$ & $-0.043^{* * *}$ & $-0.043^{* * *}$ \\
\hline & $(-8.28)$ & $(-8.40)$ & $(-8.52)$ & $(-8.51)$ & $(-8.44)$ \\
\hline \multirow[t]{2}{*}{ Privately Owned Firm } & 0.012 & 0.010 & 0.010 & 0.011 & 0.010 \\
\hline & $(0.83)$ & $(0.71)$ & $(0.72)$ & $(0.77)$ & $(0.69)$ \\
\hline \multirow[t]{2}{*}{ High Anti-CPI } & $0.243^{* *}$ & $0.250 * *$ & $0.246^{* *}$ & $0.229 * *$ & $0.247 * * *$ \\
\hline & $(2.46)$ & $(2.57)$ & $(2.54)$ & $(2.44)$ & $(2.64)$ \\
\hline \multirow[t]{2}{*}{ Constant } & $0.483^{* * *}$ & $0.473 * * *$ & $0.476^{* * *}$ & $0.467 * * *$ & $0.465^{* * *}$ \\
\hline & $(3.78)$ & $(3.84)$ & $(3.86)$ & $(3.96)$ & $(3.98)$ \\
\hline Observations & 6,026 & 6,026 & 6,026 & 6,026 & 6,026 \\
\hline Pseudo R-Squared & 0.241 & 0.243 & 0.242 & 0.241 & 0.244 \\
\hline Country and Industry FE? & Yes & Yes & Yes & Yes & Yes \\
\hline \multicolumn{6}{|c|}{$\begin{array}{l}\text { This table presents the multivariate regression estimates of tax evasion on various groups influencing government policy with control variables. } \\
\text { The dependent variable in each model is Tax Evasion Ratio which is equal to } 1 \text { minus the percent of sales reported as answered on the World } \\
\text { Bank Private Enterprise Survey. Own Firm Influence is a firm's perceived level of its own influence over government policy. Similarly, Other } \\
\text { Domestic Firms' Influence, Foreign Firms' Influence, and Foreign Development Agencies' Influence measure the perceived influence over } \\
\text { government policy of other domestic firms, foreign firms, and foreign development agencies/governments, respectively. High Anti-CPI measures } \\
\text { perceptions of anti-corruption by country using Transparency International's corruption perceptions index (CPI) data. CPI is inversely related to } \\
\text { the perceptions of corruption. For example, a high CPI signifies a country with a low level of government corruption. Thus, High Anti-CPI takes } \\
\text { the value of } 1 \text { if the CPI is above the sample median and } 0 \text { otherwise. Additional details related to specific variable measures and the } \\
\text { corresponding survey questions are presented in Appendix A. Control variables are as defined in Appendix A. Robust t-statistics calculated using } \\
\text { standard errors clustered by country are presented in parentheses with } * * * \text { signifying a p }<0.01 \text {, ** representing a p }<0.05 \text {, and } * \text { representing a } \\
\text { p<0.10. }\end{array}$} \\
\hline
\end{tabular}

